\title{
Urban Air Quality Studies in Mongolia: Pollution Characteristics and Future Research Needs
}

Aerosol and Air Quality Research

\section{OPEN ACCESS}

Received: July 3, 2021

Revised: September 21, 2021

Accepted: October 25, 2021

\section{${ }^{*}$ Corresponding Author:}

soyolerdene@seas.num.edu.mn

\section{Publisher:}

Taiwan Association for Aerosol Research

ISSN: $1680-8584$ print

ISSN: 2071-1409 online

(c) Copyright: The Author(s). This is an open access article distributed under the terms of the Creative Commons Attribution License (CC BY 4.0), which permits unrestricted use, distribution, and reproduction in any medium, provided the original author and source are cited.

\author{
Tseren-Ochir Soyol-Erdene ${ }^{1,2^{*}}$, Gantuya Ganbat ${ }^{3}$, Barkhasragchaa Baldorj $^{4}$ \\ ${ }^{1}$ Laboratory of Environmental Chemistry and Geochemistry, National University of Mongolia, \\ Ulaanbaatar, Mongolia \\ ${ }^{2}$ Department of Environmental and Forest Engineering, School of Engineering and Applied \\ Sciences, National University of Mongolia, Ulaanbaatar, Mongolia \\ ${ }^{3}$ German-Mongolian Institute for Resources and Technology, Nalaikh, Ulaanbaatar, Mongolia \\ ${ }^{4}$ Central Laboratory of Environmental Monitoring, National Agency of Meteorology and \\ Environmental Monitoring, Ulaanbaatar, Mongolia
}

\section{ABSTRACT}

For the last decades, Mongolia has seen an extensive escalation in population growth, urbanization, and industrialization, together with great increase in mining and usage of vehicles. As a result, a substantial increase has taken place in the types and number of emission sources of air pollutants, especially in urban areas. During the cold season, air pollution level in Ulaanbaatar, the capital of Mongolia, is frequently ranked as the highest in the world. However, due to the lack of air quality management, the country is suffering from a deterioration of air quality.

Despite the worse air pollution situation, due to insufficient research capacity of the country, to date, research works on characteristics of air pollution have mainly been based on current capability and/or collaboration with foreign institutes. The research gap in this area necessitates numerous investigations, which could have great importance in developing mitigating strategies and minimizing the adverse impact of air pollution on local and regional scales. This paper reviews previously available studies and reports in international scientific journals on air quality in Mongolia. Based on the existing research works, future needs of studies on ambient air pollution in Mongolia are suggested.

Keywords: Air pollution, Literature overview, Ulaanbaatar, Mongolia, Further research recommendations

\section{INTRODUCTION}

Asian countries have experienced substantial growth in development and urbanization coupled with increases in energy use and transportation in recent decades (Moran and Kanemoto, 2016; Bilgili et al., 2017; Li et al., 2017). A considerable increase has occurred in the number and types of emission sources of air pollutants in Asia (Moran and Kanemoto, 2016; Li et al., 2017). As a result, air pollution has emerged as a significant threat to the environment, quality of life, and health of the inhabitants in Asia, especially in developing countries where emission control system and strategies are not usually well established (Liu et al., 2016; Moran and Kanemoto, 2016). Mongolia is one of the most rapidly developing countries in the world. As an East Asian country located between China and Russia, it is known for pristine environments with largely empty grassland, cold winters, and nomadic traditional culture. After the transition from a socialist system during the Soviet Union to democratic system in the beginning of the 1990s, urbanization, population growth, industrialization, and transportation development accelerated and created various environmental stresses in both urban and rural areas in the country (Warburton et al., 2013; Pfeiffer et al., 2015; Fan et al., 2016; Batsaikhan et al., 2018). Especially in recent years, Mongolia has become known for one of the world's worst air in the winter months (Davy et al., 
2011; Cousins, 2019). The most polluted air in Mongolia is found in the capital city of Ulaanbaatar, where $46 \%$ of the country's population resides (NSOM, 2021). Furthermore, other cities in rural areas of the country are also facing a high degree of air pollution up to and exceeding the World Health Organization (WHO) and permissible levels of national guidelines (MET, 2019). The defining characteristic of air pollution in Mongolia — as in many countries - is the high concentration of particulate matter (PM) (Davy et al., 2011; Nishikawa et al., 2011; Guttikunda et al., 2013; Hasenkopf et al., 2016). It has been considered that air pollution represents a major threat to public health in Ulaanbaatar, the capital city of Mongolia (Allen et al., 2013).

In the last two decades, with worsening air quality in Ulaanbaatar, interest in addressing air pollution has been increased. A number of research works has been performed on the assessment of the ambient air quality by evaluating criteria (Luvsan et al., 2012; Huang et al., 2013) and trace (Byambaa et al., 2019; Nirmalkar et al., 2020) pollutants in Mongolia, chemical (Jung et al., 2010; Davy et al., 2011; Nishikawa et al., 2011; Batmunkh et al., 2013; Amgalan et al., 2016) and physical characteristics (Jung et al., 2011; Oyungerel et al., 2012; Hasenkopf et al., 2016) of atmospheric particulate matter, source apportionment of certain atmospheric pollutants (Davy et al., 2011; Nishikawa et al., 2011; Amgalan et al., 2016) and other climatic and socioeconomic factors impacting urban air quality (Luvsan et al., 2012; Ganbat et al., 2013; Huang et al., 2013; Ganbat and Baik, 2016). To date, there have been no systematic reviews of published studies on air pollution in Mongolia. In an effort to fill this gap in the literature, we aim to provide a systematic literature review of air pollution in Mongolia focusing on the source apportionment, physical and chemical characteristics of air pollutants, and identify areas for future research. The review is limited to articles and reports in the English language peer-reviewed scientific literature. Studies of health impacts including exposure and clinical symptoms resulting from indoor and outdoor air pollution are not discussed.

Section 2 introduces the study area and its climate, which constitutes the important factor affecting air pollution. Some characteristics of the air quality monitoring network are also described in Section 2. Section 3 presents an overview of air pollution studies in Mongolia and particularly in Ulaanbaatar. The paper recommends the directions for further research. Conclusions are given in Section 4.

\section{STUDY AREA}

Mongolia is a landlocked country in the East Asian region positioned between $41^{\circ} 40^{\prime}$ to $52^{\circ} 15^{\prime} \mathrm{N}$ and $87^{\circ} 44^{\prime}$ to $119^{\circ} 54^{\prime} \mathrm{E}$ (Fig. 1). Mongolia has a marked continental climate with a broadly latitudinal rainfall distribution, causing a steep climatic gradient from semi-arid conditions in the north, with a mean annual precipitation of up to nearly $400 \mathrm{~mm}$, to arid conditions in the south, with only $100 \mathrm{~mm}$ (Wesche and Treiber, 2012). The climate supports three main rangeland types: meadow steppe or forest steppe in the north, true steppe in the center and desert steppe in the south. The highest temperatures can reach $45^{\circ} \mathrm{C}$ in the Gobi region, which is in the southern part of the country and covered by sandy desert. Very cold and dry winters occur in the Central Northern and Northwestern mountain regions in Mongolia, with decreases in temperature to $-45^{\circ} \mathrm{C}$ (Wesche and Treiber, 2012). This cold weather is attributed to the Siberian high-pressure system, which extends southeastward across the Eurasian continent in winter. Wintertime Siberian high-pressure system is also responsible for both weak winds that prevent air from mixing near the surface and clear skies, causing the formation of temperature inversion. This condition plays a significant role in winter air pollution (Ganbat and Baik, 2016).

Mongolia is the least densely populated country in the world, with a total population of only 3.36 million in an area of 1.56 million square kilometers, and is the $18^{\text {th }}$ largest country worldwide (NSOM, 2021). The administrative division of Mongolia consists of twenty-one provinces and a capital city. Mongolia's population has undergone rapid urbanization since the mid-1990s, and this shift has had a major impact on the capital city, Ulaanbaatar, which is now home to 1.57 million people, equaling $45.4 \%$ of the nation's total population (NSOM, 2021). In addition to the capital city, each province has a city as its center, where the most populated areas within the provinces have a population of 10.7-103.7 thousands (NSOM, 2021). Two main industrial cities, Erdenet (\#23 and \#24 in Table 1 and Fig. 1) and Darkhan (\#7 in Table 1 and Fig. 1), which are the centers 


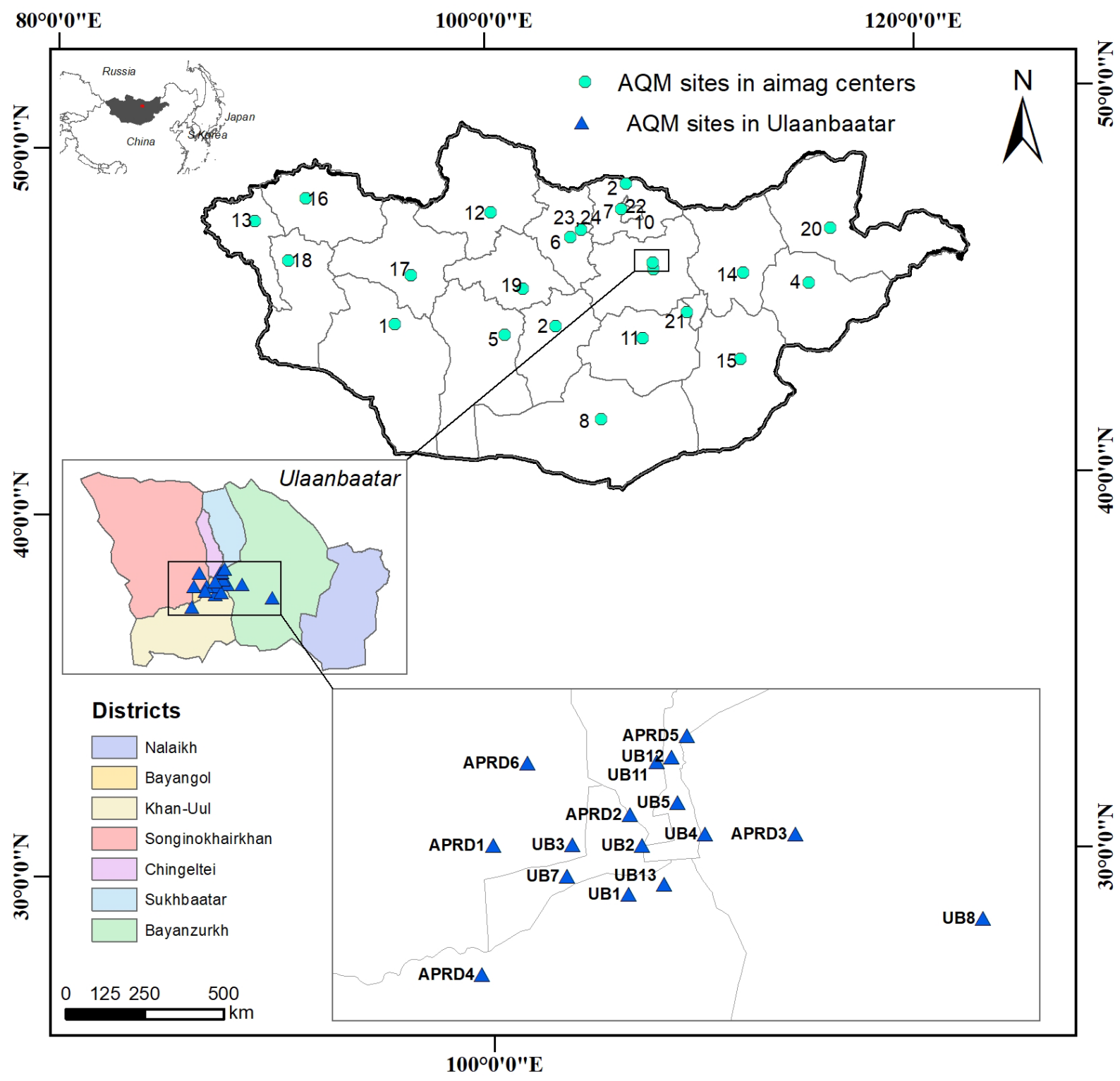

Fig. 1. Mongolia's geographic administrative boundaries and air quality monitoring sites in province centers and Ulaanbaatar. Site identifications are mentioned in Table 1.

of Orkhon and Darkhan-Uul provinces, respectively, are the most populated and industrial hub regions outside the Ulaanbaatar. The populations living in cities, both centers of provinces and the capital, have increased dramatically in recent decades (Warburton et al., 2013). The urban population occupied $57 \%$ (1.226 million) of the total population of 2.153 million in 1990 , and as of 2020, it had increased by a factor of two, reaching $69 \%$ (2.316 million) of the total population of the country (NSOM, 2021).

Ambient air pollution is the main environmental issue in the cities of Mongolia. Because of its high population and air pollution emission rate coupled with geographical and climatic conditions, air pollution is the most serious in Ulaanbaatar (Cousins, 2019). Other cities (the centers of the provinces including major industrial cities - Darkhan and Erdenet) have also been experiencing a high degree of ambient air pollution in recent years, especially during the winter season (MET, 2019).

Through the air quality (AQ) monitoring network, which constitutes of the National Agency for Meteorology and Environmental Monitoring (NAMEM) and the Air Pollution Reduction Department of Ulaanbaatar city (APRD), a total of 42 sites are operating across the country (Fig. 1). At the site, sulfur dioxide $\left(\mathrm{SO}_{2}\right)$, nitrogen dioxide $\left(\mathrm{NO}_{2}\right)$, and particulate matters $\left(\mathrm{PM}_{10}\right.$ and $\left.\mathrm{PM}_{2.5}\right)$ are monitored 
Table 1. List of the air quality monitoring sites with measured parameters in Mongolia.

\begin{tabular}{|c|c|c|c|c|c|c|c|}
\hline \multirow{2}{*}{ Site name (ID) } & \multicolumn{7}{|c|}{ Measuring parameters } \\
\hline & WP & $\mathrm{SO}_{2}$ & $\mathrm{NO}_{\mathrm{x}}$ & $\mathrm{CO}$ & $\mathrm{O}_{3}$ & $\mathrm{PM}_{2.5}$ & $\mathrm{PM}_{10}$ \\
\hline \multicolumn{8}{|l|}{ Ulaanbaatar city } \\
\hline Uildver (UB1) & O & O & O & O & O & - & 0 \\
\hline Baruun 4 zam (UB2) & o & o & O & o & - & o & o \\
\hline 1-r horoolol (UB3) & ० & O & O & ० & o & o & o \\
\hline Zuun 4 zam (UB4) & o & o & O & o & O & o & o \\
\hline Zuun ail (UB5) & o & o & o & o & ० & - & o \\
\hline Mongol gazar (UB7) & o & o & o & o & - & - & o \\
\hline Urgakh naran (UB8) & o & o & O & o & o & - & o \\
\hline Selbe 5 buudal (UB12) & - & o & O & - & - & o & o \\
\hline Hailaast (UB11) & - & o & O & - & - & - & ○ \\
\hline Bogdkhaanii ordon museum (UB13) & - & o & O & o & - & 0 & o \\
\hline Tolgoit (APRD1) & ० & o & ○ & o & ○ & o & - \\
\hline MNB (APRD2) & ० & O & O & ० & O & ० & - \\
\hline Amgalan (APRD3) & ० & o & O & o & o & o & - \\
\hline Nisekh (APRD4) & ○ & o & ○ & o & o & o & o \\
\hline Dambadarjaa (APRD5) & - & O & ○ & ० & - & o & ० \\
\hline Bayankhoshuu (APRD6) & o & o & - & - & - & o & o \\
\hline \multicolumn{8}{|l|}{ Other cities (province centers) } \\
\hline 1-Altai & $\triangle$ & o & O & - & - & - & - \\
\hline 2-Arvaikheer & $\triangle$ & o & O & - & - & - & - \\
\hline 3-Baganuur & $\triangle$ & ○ & ○ & - & - & - & - \\
\hline 4-Baruun-Urt & $\triangle$ & o & O & - & - & - & - \\
\hline 5-Bayankhongor & $\triangle$ & o & o & - & - & - & o \\
\hline 6-Bulgan & $\triangle$ & o & o & - & - & - & - \\
\hline 7-Darkhan-1 & $\triangle$ & o & O & - & - & - & 0 \\
\hline 8-Dalanzadgad & $\triangle$ & o & O & - & - & - & - \\
\hline 9-Zuunmod & $\triangle$ & o & o & - & - & - & - \\
\hline 10-Zuunkharaa & $\triangle$ & o & o & - & - & - & - \\
\hline 11-Mandalgobi & $\triangle$ & o & O & - & - & - & - \\
\hline 12-Murun & $\triangle$ & o & o & - & - & - & ० \\
\hline 13-Ulgii & $\triangle$ & o & 0 & - & - & - & - \\
\hline 14-Undurkhaan & $\triangle$ & o & O & - & - & - & - \\
\hline 15-Sainshand & $\triangle$ & o & o & - & - & - & - \\
\hline 16-Ulaangom & $\triangle$ & o & o & - & - & - & - \\
\hline 17-Uliastai & $\triangle$ & o & O & - & - & - & - \\
\hline 18-Khovd & $\triangle$ & 0 & 0 & - & - & - & - \\
\hline 19-Tsetserleg & $\triangle$ & o & 0 & - & - & - & - \\
\hline 20-Choibalsan & $\triangle$ & 0 & o & - & - & - & - \\
\hline 21-Choir & $\triangle$ & o & O & - & - & - & - \\
\hline 22-Shariin gol & $\triangle$ & 0 & 0 & - & - & - & - \\
\hline 23-Erdenet-1 & $\triangle$ & o & O & - & - & - & ० \\
\hline 24-Erdenet-2 & $\triangle$ & 0 & 0 & - & - & - & \\
\hline 25-Sukhbaatar & $\triangle$ & 0 & 0 & - & - & - & - \\
\hline
\end{tabular}

WP: weather parameters; o Measure; - Not measure; $\triangle$ Measure at local weather station.

regularly. Only a few sites in Ulaanbaatar measure ozone $\left(\mathrm{O}_{3}\right)$ and carbon monoxide (CO) concentrations. The numbers of measuring parameters vary between the sites. The AQ monitoring sites of Mongolia with the measured parameters is listed in Table 1. Sixteen air quality monitoring sites are operated in Ulaanbaatar and located in -industrial (UB1 and UB7), residential (UB4, UB5 and UB13), ger area (UB3, UB11, UB12, APRD1, APRD2, APRD3, APRD4, APRD5, and APRD6), roadside (UB2), and remote areas (UB8). The current national air quality standard (MNS 4585:2016) 
designating the maximum permissible levels of pollutants in ambient air was last amended in 2016. The pollutant levels in the national standard are high in comparison with those in the WHO guidelines (UNDP, 2019). For example, the national standard for 24-hour $\mathrm{PM}_{2.5}$ is $50 \mu \mathrm{g} \mathrm{m}^{-3}$, while the WHO standard is $25 \mu \mathrm{g} \mathrm{m} \mathrm{m}^{-3}$ (Table 2.2 from UNDP (2019)). The air quality index is used to report the air quality situation to the public and has been revised and implemented in 2018 based on the effects of air pollutant concentrations on human health (MET, 2018).

\section{RESULTS AND DISCUSSION}

\subsection{Pollutant Sources}

For decision-makers, accurate and up-to-date knowledge of the source apportionment is essential in developing an optimal air quality management program. There is a lack of studies focusing on the source apportionment of air pollution and emission inventory except for Ulaanbaatar. Several published reports and studies on the air pollution sources in Ulaanbaatar are available. For the first time, Guttikunda (2008) presented the sources of particulate matter emissions for 2006. A local source predominates over the long-range transport (Nishikawa et al., 2011). The PM emitters were reported to be from power plants (36\%), followed by household stoves (25\%) and heat-only boilers (17\%). At the ground level in the city, it was calculated that stoves and HOBs (heat-only boilers) contribute the most to air pollution. The largest source of $\mathrm{PM}_{10}$ is household stoves and HOBs, which were indicated at ground level in the city (Guttikunda, 2008). It was mentioned that the PM source from vehicles is less important than that from power plants, stoves, and boilers, however, is increasing rapidly than the other sectors (Guttikunda, 2008).

The PM pollution source from combustion processes in stoves is also found to be significant ( $87 \%)$ from the analysis done in 2008-2009 (Lodoysamba and Pemberton-Pigott, 2011). The different averaging period and spatial location showed different contributions; for example, the difference between the contributions from combustion sources for $\mathrm{PM}_{2.5}$ for 1-year and 5-year is 35\%, and locations near ger (Mongolian traditional felt tent) areas showed the highest contributions from combustion.

The emission inventory has been updated and reported within the Capacity Development Project for Air pollution control supported by the Japan International Cooperation Agency (JICA, 2017). The source contributions of individual PM, sulfate, and nitrate in Ulaanbaatar were identified. The pollution source contributions are likely to show spatial variations; for example, power plants in southern Ulaanbaatar show the largest contribution to $\mathrm{PM}_{10}$ emission sources, along with stoves, dust from roads and vehicle exhaust gas, while roads tend to show greater source contributions, followed by stoves in another part of Ulaanbaatar. Contributions from different sources may also depend on the emission height, e.g., stack height is $150-250 \mathrm{~m}$ for power plants, $\sim 10-40 \mathrm{~m}$ for HOBs and $\sim 3-6$ m only for households' stoves.

\subsection{Air Quality Studies in Small and Industrial Cities}

In this section, ambient air quality studies in the central towns of the twenty-one provinces of Mongolia are considered. Within the framework of the National Environmental Monitoring System, criteria pollutants are monitored (Table 1 ) at the air quality (AQ) monitoring sites. Due to scattered sites of the national network, small and industrial cities have difficulty in getting detailed information on air quality. Nevertheless, according to the observation results, the main pollutants that show comparably higher concentrations and risks for human health overall in Mongolia are $\mathrm{SO}_{2}, \mathrm{NO}_{2}$, and $\mathrm{PM}$, while $\mathrm{CO}$ and $\mathrm{O}_{3}$ are below the national standard levels.

\subsubsection{Gaseous pollutants}

Fig. 2 shows the comparison of monthly mean concentrations for December of $\mathrm{SO}_{2}$ and $\mathrm{NO}_{2}$ for 2013-2015 and 2017-2019 periods measured at the AQ monitoring sites in non-capital locations. December month is chosen because it is the second coldest and polluted month of the year in the region. The concentrations of air pollutants vary across the country which are likely to be associated with various factors, such as pollutant sources, geographical and climate conditions, and socioeconomic factors. The mean $\mathrm{SO}_{2}$ concentrations for December varied in the range of 

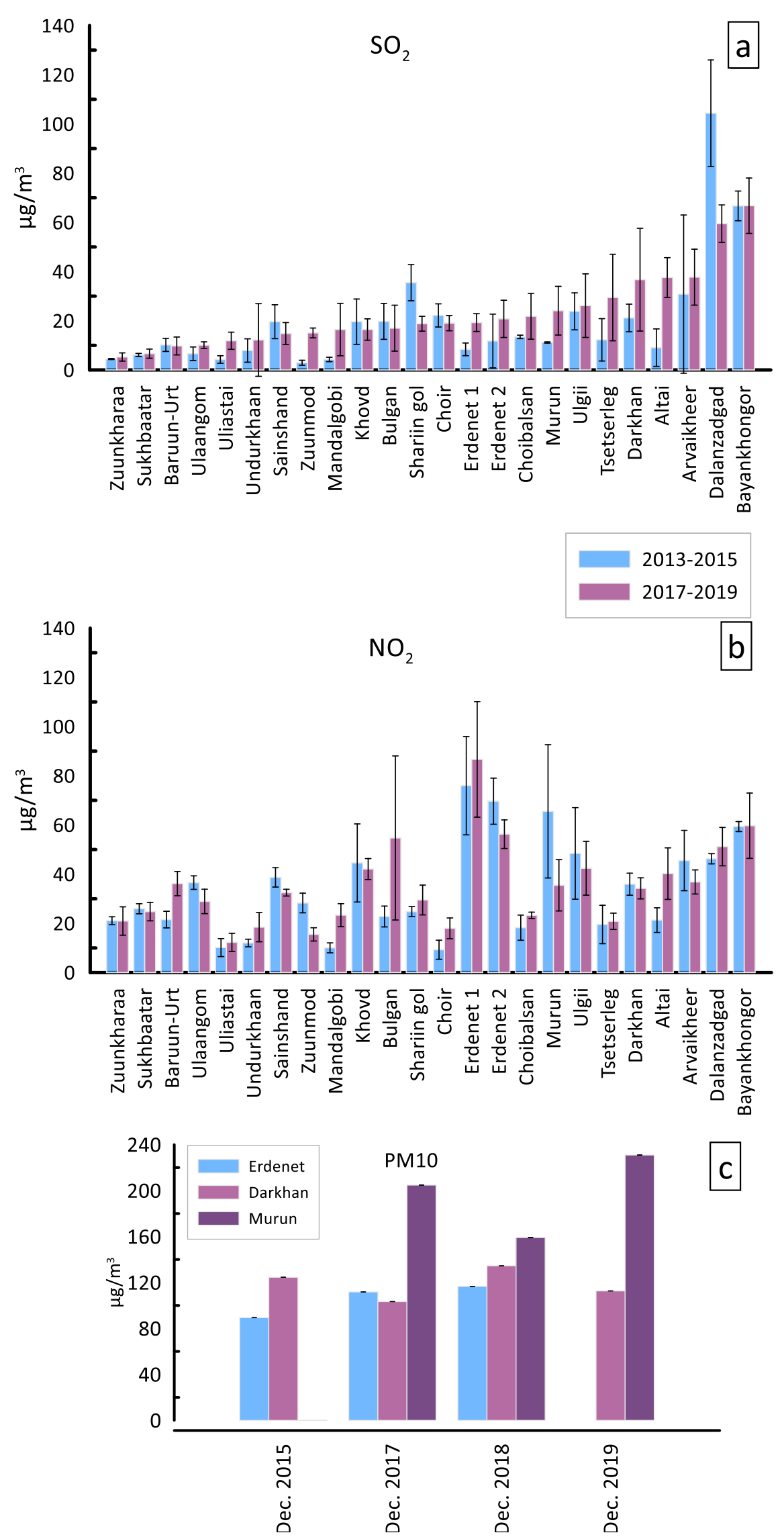

Fig. 2. Monthly mean concentrations for December of (a) $\mathrm{SO}_{2}$, (b) $\mathrm{NO}_{2}$, and (c) $\mathrm{PM}_{10}$ at the air quality monitoring sites. 
2.2-117 $\mu \mathrm{g} \mathrm{m}^{-3}$ (not shown here) at the AQ monitoring sites and exceeded the permissible level (50 $\mu \mathrm{g} \mathrm{m}^{-3}$, the daily mean) in Bayankhongor (\#5 in Fig. 1 and Table 1) and Dalanzadgad (\#8 in Fig. 1 and Table 1) in 2018 (Fig. 2(a)). The mean $\mathrm{NO}_{2}$ concentrations for December of each year at the $\mathrm{AQ}$ monitoring sites varied in the range of 6.4-112 $\mu \mathrm{g} \mathrm{m}^{-3}$ (not shown here). In Bayankhongor and Erdenet, high levels of $\mathrm{NO}_{2}$ were observed, exceeding the national permissible level $\left(50 \mu \mathrm{g} \mathrm{m}^{-3}\right.$, daily mean) (Fig. 2(b)). Air quality monitoring sites in Bayankhongor and Erdenet are located on roadside and the numbers of automobiles in the cities are dramatically increased in recent years. According to the National Statistical Office of Mongolia, the numbers of automobiles are increased by factor of $\sim 1.8$ in Orkhon province ( $96 \%$ of population lives in the Erdenet city) for the last eight years (NSOM, 2020). During the period from 2017 to 2019, the mean concentration of $\mathrm{SO}_{2}$ for December clearly increased for the most sites in comparison with period from 2013 through 2015 (Fig. 2(a)). Luvsan et al. (2012) discussed regular monitoring data of $\mathrm{SO}_{2}$ from $10 \mathrm{AQ}$ monitoring sites in cities (Khovd, Ulaangom, Murun, Tsetserleg, Arvaikheer, Mandalgobi, Darkhan, Sukhbaatar, Erdenet, and Choibalsan) and four AQ monitoring sites (UB1 to UB4) of Ulaanbaatar for the period 1996-2009 to determine the source area of sulfur dioxide in Mongolia. Clear seasonal variations in $\mathrm{SO}_{2}$ associated with heating demand in harsh winter and increased emissions from urbanization and industrialization were seen and the annual mean concentrations of $\mathrm{SO}_{2}$ are likely to rise with increasing population and industrial development (Luvsan et al., 2012). Moreover, the steel industry, mining, and/or other industrial activities can be major contributors to air pollution in Darkhan, Erdenet, and Sukhbaatar (Luvsan et al., 2012).

\subsubsection{Particulate matter}

As mentioned, particulate matter is the most common polluting parameter in Mongolia due to emissions from incomplete coal combustion in households and soil resuspended dust. Fig. 2(c) shows December mean concentration of $\mathrm{PM}_{10}$ at three local sites - Erdenet, Darkhan, and Murun for the period of 2015-2019. As shown in Fig. 2(c), the $\mathrm{PM}_{10}$ concentration exceeds the national permissible level at the sites (100 $\mu \mathrm{g} \mathrm{m}^{-3}$, daily mean), with monthly average concentrations ranging between $89 \mu \mathrm{g} \mathrm{m}^{-3}$ (in Erdenet in 2015) and $230 \mu \mathrm{g} \mathrm{m}^{-3}$ (in Murun in 2019) in winter. Bolor-Erdene et al. (2011) conducted an analysis of $\mathrm{PM}_{10}$ and $\mathrm{PM}_{2.5}$ mass concentrations and their elemental compositions in ambient air in the cities of Erdenet and Ulaanbaatar, but detailed information about the sampling period and concentration for the Erdenet cities was not provided (Bolor-Erdene et al., 2011).

\subsubsection{Trends of air quality in small cities}

According to a report from the Ministry of Environment and Tourism (MET, 2020), the air quality in many cities of Mongolia is getting worse each year. Variations in the yearly mean concentrations of $\mathrm{SO}_{2}$ at three sites (Bayankhongor, Darkhan, and Arvaikheer, Fig. 2(a)) illustrate a dramatic increase of 50-90\% for the 2009-2011 period. In addition to the continuous increase in the pollution level of ambient air in many small and industrial cities of Mongolia, detailed research works on both criteria and trace pollutants - spatial and temporal variations, risk assessment, source characteristics, and socioeconomic, geographical, and climatic condition impacts were not yet systematically investigated or published in international scientific journals. Only two works (Bolor-Erdene et al., 2011; Luvsan et al., 2012) considered a few air pollution parameters outside of the capital city Ulaanbaatar. Both studies noticed clear seasonal variations in pollution levels in ambient air at all investigated sites, with the greatest variations occurring from December to February. The major sources are household and heat power stations' fuel burning for heating, which impacts the seasonal frequency of these air pollutants in Mongolia (Luvsan et al., 2012). Moreover, mining waste dump can have a significant contribution to ambient PM pollution in Erdenet city (Bolor-Erdene et al., 2011). Air pollution from $\mathrm{SO}_{2}$ in small cities of Mongolia is becoming worse as urbanization (Luvsan et al., 2012) and energy use increase.

\subsection{Air Quality Studies in Ulaanbaatar City}

Ulaanbaatar, Mongolia, is known as one of the most severely polluted cities in the world (Cousins, 2019). Ulaanbaatar's air pollution has become of increasing concern in recent two decades. Table 2 summarizes international publications focusing ambient air pollution and related 
Table 2. Compilation of published studies on ambient air quality in Mongolia.

\begin{tabular}{|c|c|c|c|c|}
\hline Study & $\begin{array}{l}\text { Study area } \\
\text { (number of sites) }\end{array}$ & Focus & $\begin{array}{l}\text { Considered pollutants and data } \\
\text { collection }\end{array}$ & Study period \\
\hline $\begin{array}{l}\text { Guttikunda et } \\
\text { al. (2013) }\end{array}$ & UB & $\begin{array}{l}\text { - General discussion of PM } \\
\text { pollution }\end{array}$ & $\begin{array}{l}\text { Emission inventory of PM, } \\
\mathrm{SO}_{2}, \mathrm{NO}_{x}, \mathrm{CO}_{2} \text { for } 2010 ; \\
\text { forward trajectory modeling } \\
\text { to estimate PM } \\
\text { concentration }\end{array}$ & 2010 \\
\hline $\begin{array}{l}\text { Amarsaikhan } \\
\text { et al. (2014) }\end{array}$ & UB & $\begin{array}{l}\text { - General discussions of air } \\
\text { pollution }\end{array}$ & $\begin{array}{l}\text { - Recall of previously reported } \\
\text { studies }\end{array}$ & $\begin{array}{l}\text { Recall studies covering } \\
\text { 2007-2013 }\end{array}$ \\
\hline $\begin{array}{l}\text { Lodoysamba } \\
\text { and } \\
\text { Pemberton- } \\
\text { Pigott (2011) }\end{array}$ & UB & - Emission inventory & $\begin{array}{l}\text { - PM measurement } \\
\text { - Multi-element analysis using } \\
\text { the ion beam method } \\
\text { - Source apportionment }\end{array}$ & $2008-2009$ \\
\hline $\begin{array}{l}\text { Ganbat and } \\
\text { Baik (2016) }\end{array}$ & UB & $\begin{array}{l}\text { - Weather and topographic } \\
\text { condition }\end{array}$ & $\begin{array}{l}\text { - Meteorological condition } \\
\text { analysis } \\
\text { - Numerical weather modeling }\end{array}$ & 2013 \\
\hline $\begin{array}{l}\text { Wang et al. } \\
(2018)\end{array}$ & UB & $\begin{array}{l}\text { - Impact of meteorological } \\
\text { condition on air pollution }\end{array}$ & $\begin{array}{l}\text { - Analysis of meteorological, } \\
\text { air quality (PM), ground } \\
\text { based LIDAR, and radiosonde } \\
\text { data }\end{array}$ & 2008-2016 \\
\hline $\begin{array}{l}\text { Wang et al. } \\
\text { (2017) }\end{array}$ & UB & $\begin{array}{l}\text { Impact of meteorological } \\
\text { condition on air particulate } \\
\text { pollution }\end{array}$ & $\begin{array}{l}\text { - Analysis of meteorological } \\
\text { and LIDAR data }\end{array}$ & 2010 \\
\hline $\begin{array}{l}\text { Prikaz et al. } \\
\text { (2018) }\end{array}$ & UB (1) & $\begin{array}{l}\text { - Source area of } \mathrm{SO}_{2} \text { by } \\
\text { HYPSLIT model }\end{array}$ & $\begin{array}{l}\text { - } \mathrm{NO}_{x}, \mathrm{NO}, \mathrm{NO}_{2}, \mathrm{O}_{3}, \mathrm{CO}, \mathrm{PM}_{10} \\
\mathrm{PM}_{2.5}, \mathrm{PM}_{1} \text { from National } \\
\text { monitoring network }\end{array}$ & Over 2017 \\
\hline $\begin{array}{l}\text { Luvsan et al. } \\
(2012)\end{array}$ & $\begin{array}{l}\text { UB (4) } \\
\text { Provinces (10) }\end{array}$ & $\begin{array}{l}\text { - Influence of sources and } \\
\text { meteorological conditions } \\
\text { on } \mathrm{SO}_{2} \text { pollution by } \\
\text { multiple regression models }\end{array}$ & $\begin{array}{l}\text { - } \mathrm{SO}_{2} \text { data from National } \\
\text { monitoring network }\end{array}$ & Multiyear (1996-2009) \\
\hline $\begin{array}{l}\text { Bolor-Erdene } \\
\text { et al. (2011) }\end{array}$ & $\begin{array}{l}\text { UB (1) } \\
\text { Erdenet (1) }\end{array}$ & $\begin{array}{l}\text { - Mass concentration } \\
\text { - Elemental composition of } \\
\mathrm{PM}_{2.5} \text { and } \mathrm{PM}_{2.5-10}\end{array}$ & $\begin{array}{l}\text { - } \mathrm{PM}_{10-2.5}, \mathrm{PM}_{2.5} \text { sampling } \\
\text { - Elemental analyses by XRF }\end{array}$ & No information provided \\
\hline $\begin{array}{l}\text { Huang et al. } \\
\text { (2013) }\end{array}$ & UB (38) & $\begin{array}{l}\text { - Source contributions for } \\
\mathrm{SO}_{2} \text { and } \mathrm{NO}_{2} \text { using land use } \\
\text { regression model }\end{array}$ & $\begin{array}{l}\text { - } \mathrm{SO}_{2}, \mathrm{NO}_{2} \text { by } 2 \text { weeks passive } \\
\text { sampling, analyses }\end{array}$ & $\begin{array}{l}\text { Three different seasons } \\
\text { (Sep. 2011-Mar. 2012) }\end{array}$ \\
\hline $\begin{array}{l}\text { Amgalan et al. } \\
(2016)\end{array}$ & UB (2) & $\begin{array}{l}\text { - Elemental composition, } \\
\text { - Source contributions PMF } \\
\text { model }\end{array}$ & $\begin{array}{l}\text { - Sampling of } \mathrm{PM}_{0-2.2}, \mathrm{PM}_{2.2-10} \\
\text { - Elemental analyses by XRF }\end{array}$ & $\begin{array}{l}\text { Over } 1 \text { year (Sep. 2012- } \\
\text { Aug. 2013) }\end{array}$ \\
\hline $\begin{array}{l}\text { Batmunkh et } \\
\text { al. (2013) }\end{array}$ & UB (1) & $\begin{array}{l}\text { - Chemical characteristics of } \\
\text { atmospheric aerosol during } \\
\text { winter }\end{array}$ & $\begin{array}{l}\text { - } \mathrm{PM}_{2.5} \text { sampling } \\
\text { - mass concentration chemical } \\
\text { analyses for ions, metals, } \\
\text { OC, EC }\end{array}$ & $\begin{array}{l}\text { One season (Jan. 2008- } \\
\text { Feb. 2008) }\end{array}$ \\
\hline $\begin{array}{l}\text { Byambaa et al. } \\
\text { (2019) }\end{array}$ & UB (5) & $\begin{array}{l}\text { - Source contribution } \\
\text { prediction of PAHs in } \\
\text { ambient TSP } \\
\text { - Health risk assessment } \\
\text { based on concentrations }\end{array}$ & - 15 priority PAHs & $\begin{array}{l}\text { 1-week sampling at } \\
\text { three seasons (Jan. 2017, } \\
\text { Mar. 2017, Sep. 2017) }\end{array}$ \\
\hline $\begin{array}{l}\text { Hasenkopf et } \\
\text { al. (2016) }\end{array}$ & UB (1) & $\begin{array}{l}\text { - Elemental composition of } \\
\mathrm{PM}_{2.5} \\
\text { - Physical characterization of } \\
\mathrm{PM}_{2.5}\end{array}$ & $\begin{array}{l}\text { - } \mathrm{PM}_{2.5} \text { mass concentration } \\
\text { - Elemental analyses } \\
\text { - Determination of particle } \\
\text { size, shape, and ice } \\
\text { nucleation }\end{array}$ & $\begin{array}{l}\text { Nine months (Jun. 2012- } \\
\text { Feb. 2013) }\end{array}$ \\
\hline
\end{tabular}


Table 2. (continued).

\begin{tabular}{|c|c|c|c|c|}
\hline Study & $\begin{array}{l}\text { Study area } \\
\text { (number of sites) }\end{array}$ & Focus & $\begin{array}{l}\text { Considered pollutants and data } \\
\text { collection }\end{array}$ & Study period \\
\hline $\begin{array}{l}\text { Davy et al. } \\
\text { (2011) }\end{array}$ & UB (1) & $\begin{array}{l}\text { - PM mass concentration } \\
\text { - Elemental composition, } \\
\text { source contributions by } \\
\text { PMF model }\end{array}$ & $\begin{array}{l}\text { - } \mathrm{PM}_{10-2.5}, \mathrm{PM}_{2.5} \text { sampling } \\
\text { - Elemental analyses by XRF }\end{array}$ & $\begin{array}{l}\text { Multiyear (Oct. 2004- } \\
\text { Apr. 2008) }\end{array}$ \\
\hline $\begin{array}{l}\text { Gunchin et al. } \\
\text { (2019) }\end{array}$ & UB & $\begin{array}{l}\text { - PM mass concentration } \\
\text { - Elemental composition, } \\
\text { source contributions by } \\
\text { PMF model }\end{array}$ & $\begin{array}{l}\text { - } \mathrm{PM}_{10-2.5}, \mathrm{PM}_{2.5} \text {, sampling } \\
\text { - Elemental analyses by XRF }\end{array}$ & $\begin{array}{l}\text { Multiyear (Jan. 2014- } \\
\text { Jan. 2017) }\end{array}$ \\
\hline $\begin{array}{l}\text { Nishikawa et } \\
\text { al. (2011) }\end{array}$ & UB (1) & $\begin{array}{l}\text { - Two seasons chemical } \\
\text { composition of } \mathrm{PM}_{10} \\
\text { - Monitoring } \mathrm{PM}_{2.5} \text { and } \mathrm{PM}_{10}\end{array}$ & $\begin{array}{l}\text { - } \mathrm{PM}_{10} \text { sampling and analyses } \\
\text { for ions, elements, } \mathrm{OC}, \mathrm{EC}, \mathrm{C} \\
\text { isotope composition in } \mathrm{OC} \\
\text { - } \mathrm{PM}_{2.5}, \mathrm{SO}_{2}, \mathrm{PM}_{10}\end{array}$ & $\begin{array}{l}\text { - } \mathrm{PM}_{10} \text { sampling: 1-week } \\
\text { each season (Jan. } \\
\text { 2008; Jun. 2008) } \\
\text { - } \mathrm{PM}_{2.5}, \mathrm{SO}_{2}, \mathrm{PM}_{10}-\mathrm{Over} \\
\text { a year (Jun. 2009-May } \\
\text { 2010) }\end{array}$ \\
\hline $\begin{array}{l}\text { Oyungerel et } \\
\text { al. (2013) }\end{array}$ & UB (12) & $\begin{array}{l}\text { Particle sizes and their } \\
\text { distributions of roadside } \\
\text { aerosols }\end{array}$ & - Particles in snow samples & $\begin{array}{l}\text { January } 2011 \text { (total } \\
\text { accumulated snow) }\end{array}$ \\
\hline $\begin{array}{l}\text { Jung et al. } \\
\text { (2010) }\end{array}$ & UB (1) & $\begin{array}{l}\text { - Composition of water- } \\
\text { soluble organic acids in } \\
\text { atmospheric fine PM during } \\
\text { winter haze period }\end{array}$ & $\begin{array}{l}\text { - } \mathrm{PM}_{2.5} \text { sampling } \\
\text { - Analyses of } 40 \text { water soluble } \\
\text { organic acids }\end{array}$ & Dec. 2007 \\
\hline $\begin{array}{l}\text { Jung et al. } \\
\text { (2011) }\end{array}$ & UB (1) & $\begin{array}{l}\text { Hydrophobic property of } \\
\text { water-soluble organic rich } \\
\text { aerosols }\end{array}$ & 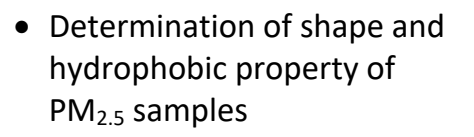 & Dec. 2007 \\
\hline $\begin{array}{l}\text { Lee et al. } \\
(2018)\end{array}$ & UB (2) & $\begin{array}{l}\text { - Comparison size and } \\
\text { chemical composition of } \\
<2.5 \mu \mathrm{m} \text { of road dust in } \\
\text { Ulaanbaatar and in } \\
\text { Gwangju, Korea. }\end{array}$ & $\begin{array}{l}\text { - Size and chemical } \\
\text { composition of }<2.5 \mu \mathrm{m} \\
\text { dust; metals, ions, } \\
\text { carbonaceous compounds }\end{array}$ & Jan. 2016 \\
\hline $\begin{array}{l}\text { Morino et al. } \\
(2008)\end{array}$ & UB (2) & $\begin{array}{l}\text { - VOC concentration in } \\
\text { ambient air }\end{array}$ & - $12 \mathrm{VOC}$ in ambient air & No information provided \\
\hline $\begin{array}{l}\text { Ganbat et al. } \\
(2020)\end{array}$ & UB (12) & - Improvement in air quality & $\begin{array}{l}\text { - Reduction of } \mathrm{PM}_{2.5} \text { and } \mathrm{PM}_{10} \\
\text { concentrations }\end{array}$ & Multiyear (2014-2020) \\
\hline $\begin{array}{l}\text { Batbold et al. } \\
(2021)\end{array}$ & UB (57) & $\begin{array}{l}\text { - Source apportionment of } \\
\text { heavy metals from ground } \\
\text { surface }\end{array}$ & $\begin{array}{l}\text { Determination of heavy } \\
\text { metal source from settled } \\
\text { dust samples }\end{array}$ & Jan. 2020 \\
\hline $\begin{array}{l}\text { Nirmalkar et } \\
\text { al. (2020) }\end{array}$ & & $\begin{array}{l}\text { Biomass burning } \\
\text { contribution } \mathrm{OC} \text { in } \mathrm{PM}_{2.5}\end{array}$ & $\begin{array}{l}\text { - } \mathrm{PM}_{2.5} \text { sampling and analyses } \\
\text { of biomass burning markers } \\
\text { (levoglugocsan/mannosan), } \\
\text { EC, OC, water soluble ions } \\
\text { - Data analyses for } \\
\text { contribution of biomass } \\
\text { burning and non-biomass } \\
\text { burning sources in OC }\end{array}$ & $\begin{array}{l}\text { Jan.-Feb. and Apr.-May } \\
2017\end{array}$ \\
\hline $\begin{array}{l}\text { Gunchin et al. } \\
\text { (2021) }\end{array}$ & UB (1) & $\begin{array}{l}\text { - Chemical speciation of } \mathrm{Zn} \\
\text { and } \mathrm{Cr} \text { in PM }\end{array}$ & $\begin{array}{l}\text { - PM sampling and analysis by } \\
\text { XANES }\end{array}$ & Jun. 2016-Jan. 2017 \\
\hline $\begin{array}{l}\text { Yamamoto et } \\
\text { al. (2020) }\end{array}$ & UB (1) & $\begin{array}{l}\text { - Chemical characteristics of } \\
\text { suspended PM and sources } \\
\text { contributions }\end{array}$ & $\begin{array}{l}\text { PM analyses for OC, metals, } \\
\text { ions, n-alkanes and PAHs }\end{array}$ & Jan. 2014-Apr. 2015 \\
\hline
\end{tabular}


topics mentioned above in Mongolia. Almost all studies conducted on the Ulaanbaatar's air pollution (Table 2), while only two works considered the air pollution in other cities (Bolor-Erdene et al., 2011; Luvsan et al., 2012). To date, ambient air quality and its related topics including chemical composition for both critical and trace (emergent) pollutants, toxicity, physical properties, source characteristics and apportionment, and distribution have been insufficiently studied (see also Fig. 1 of Hasenkopf et al., 2016) (Hasenkopf et al., 2016).

\subsubsection{Impacts of climate and topographic conditions}

Geographical and weather conditions are important factors affecting air pollution in Ulaanbaatar (Guttikunda et al., 2013). Considering how weather conditions affect air pollution may help understand the essence of air pollution and is important for appropriate reduction measures. Studies attempting to explain the weather and geographical impacts on air pollution in Ulaanbaatar have applied different methods. The city of Ulaanbaatar is located in the valley of Tuul River and surrounded by high mountains (Amarsaikhan et al., 2014). Due to complex topography, the pollutant dispersion is complex in Ulaanbaatar. The valleys, for example the Selbegol valley located to the north of the city, play an important role in transporting the pollutants over/toward the city (Lorentz et al., 2019). In summertime, when the fair condition for the development of local winds is met, urban breeze circulation, mountain/valley winds are well developed (Ganbat and Baik, 2015). Well-developed winds and deep convective boundary layers are capable to transporting pollutants far away from their emission sources. Weather conditions and air circulations on a local scale in summertime (Ganbat and Baik, 2015, 2016) are very different from those in wintertime. In winter, weak local winds are developed in a stable boundary layer (Ganbat and Baik, 2016) where the motion is suppressed resulting in trapped pollutants in the shallow boundary layer. With extreme climate, Ulaanbaatar is the coldest capital of the world; the average temperature of January is $-33^{\circ} \mathrm{C}$, but the temperatures can drop below $-40^{\circ} \mathrm{C}$ (Pillarisetti et al., 2019). Temperature inversions are frequently observed in mountainous urban areas and can cause severe air pollution problems, especially in wintertime (Luvsan et al., 2012).

During winter periods, the effects of temperature inversion are enhanced because of lower mixing layer heights (Whiteman et al., 1999). Air pollutants emitted from various sources tend to be concentrated within the valley area under the temperature inversion condition, and a layer of cooler air is trapped near the ground by a layer of warmer air above that prevents any dispersion of pollutants (Baumbach and Vogt, 2003). The low wind speed within the atmospheric boundary layer accompanied by the temperature inversion condition due to the Siberian high-pressure system contributes to the increase in air pollutants in winter in Mongolia (Wang et al., 2018; Lorentz et al., 2019). Ganbat and Baik (2016) conducted a numerical modeling experiment to investigate wintertime weather conditions that are favorable for bad air quality in Ulaanbaatar. It was revealed that the air is very stable and windless within the temperature inversion layer, which leads to the stagnation of air pollutants. Spatial and temporal variations of temperature inversion in Ulaanbaatar for the chosen case are clearly presented in the numerical modeling study (Ganbat and Baik, 2016). The numerical study reveals that the temperature inversion is strong and deep in the valleys compared to that over the mountains and mountain slopes. The temperature inversion weakens in the daytime as surface heats.

Wang et al. (2018) employed statistical methods using meteorological and air quality observations, LIDAR, and radiosonde data (Wang et al., 2017; Wang et al., 2018). They elucidated the formation and breakup timing of the temperature inversion layer capping the urban area of Ulaanbaatar. A stable atmosphere persists throughout winter (Fig. 6(c) in Wang et al. (2018)) and becomes thicker and stronger from September to January. A relatively shallow mixing layer $(<300 \mathrm{~m})$, where the wind is weak and vertical convection is suppressed, allows the air pollutants to stagnate within it. Using observational data for the period 2008-2016, the authors presented a significant positive correlation $(R=0.595)$ between the temperature inversion intensity and $\mathrm{PM}_{2.5}$ concentration in Ulaanbaatar (Wang et al., 2017, 2018).

Statistical analysis of meteorological impacts on $\mathrm{SO}_{2}$ concentration at 14 different sites in Mongolia was conducted by Luvsan et al. (2012). Linear regression model confirmed that $\mathrm{SO}_{2}$ levels are negatively correlated with wind speed and temperature in Ulaanbaatar and $\mathrm{SO}_{2}$ pollution has worsened since 2000 s because of social impacts including urbanization and industrialization. 
The authors mentioned the importance of wind directions in the increase in $\mathrm{SO}_{2}$ levels due to coal consumption emissions in ger areas. $\mathrm{SO}_{2}$ levels tend to be higher with winds from N-NNW (northnorth northwest) than those from N-ENE (north-east northeast) (Luvsan et al., 2012). Considering the studies on relationship between air pollutant concentrations and several meteorological conditions are insufficient, more sophisticated numerical modeling approach should be applied to understand the complex mechanisms.

\subsubsection{Particulate matter}

\subsubsection{Mass concentration}

The concentration of inhalable particulate matter $\left(\mathrm{PM}_{10}\right.$ and $\left.\mathrm{PM}_{2.5}\right)$ in Ulaanbaatar is the highest in the country, making Ulaanbaatar city one of the most polluted cities in the world for several years (Guttikunda et al., 2013; Cousins, 2019). Due to incomplete combustion in traditional low-efficiency stoves in ger area of Ulaanbaatar, high-concentration particulate matter is emitted from stacks of those stoves. These emissions (from 25\% (Guttikunda, 2008) to 87\% (Lodoysamba and Pemberton-Pigott, 2011)) result in extremely high concentrations of particulate matter in the urban atmosphere.

Fig. 3 shows the daily mean $\mathrm{PM}_{10}, \mathrm{PM}_{2.5}, \mathrm{SO}_{2}$, and $\mathrm{NO}_{2}$ concentrations for 2014-2021 averaged over the $A Q$ monitoring sites in Ulaanbaatar. Prominent seasonal variations are clearly seen having the greatest concentration in cold seasons due to high pollutant emissions resulting from fuel consumption and weather condition with temperature inversion (discussed in Section 3.3.1). The $\mathrm{PM}_{2.5}$ concentration is greatest in winter exceeding many times the national permissible level $\left(50 \mu \mathrm{g} \mathrm{m}^{-3}\right)$ while it is likely to be below/near the permissible level most of the time during warm, non-heating seasons. Ganbat et al. (2020) reported the daily (hourly) maximum $\mathrm{PM}_{10}$ and $\mathrm{PM}_{2.5}$ concentrations of $833.6(2505) \mu \mathrm{g} \mathrm{m}^{-3}$ and 511.4 (1413) $\mu \mathrm{g} \mathrm{m}^{-3}$ for the period, respectively (Ganbat et al., 2020).

Many studies indicated that emissions from coal burning in ger area are the main reason for Ulaanbaatar's pollution problem (Guttikunda et al., 2013; Lodoysamba and Pemberton-Pigott, 2011; JICA, 2017). Over the last decade, a variety of efforts have been made to reduce emissions from polluting sources, special attention has been paid to reduce emissions from ger areas because of coal combustion. A city-wide substitution of raw coal with upgraded briquette coal has been effective in reducing particulate matter pollution and largely reduced the $\mathrm{PM}_{2.5}$ and $\mathrm{PM}_{10}$ concentrations in winter. In the past two winters, the air quality was improved in Ulaanbaatar to some extent which was first documented in Ganbat et al. (2020). For winter 2019-2020, the daily mean concentrations of $\mathrm{PM}_{2.5}$ and $\mathrm{PM}_{10}$ during the heating season were reduced by $36 \%$ and $40 \%$ compared to the heating seasons in 2014-2018, respectively. The improvement was mainly by the city-wide substitution of raw coal with upgraded briquette fuel since 15 May 2019 according to Governmental resolution No. 62 adopted in 2018. Despite the progress in reductions in PM concentrations, the PM concentrations are still well above the WHO guideline values and the national standard levels.

\subsubsection{Chemical composition}

\section{a) Elemental composition}

Various organic and inorganic toxic substances can be present on particulate matter emitted from coal combustion as soot and ash particles. The elemental compositions of fine particulate matter in Ulaanbaatar ambient air were previously investigated in several locations by separating two different sizes of fine (aerodynamic diameter less than $2.5 \mu \mathrm{m}$ ) and coarse (between 2.5 and $10 \mu \mathrm{m}$ ) fractions (Davy et al., 2011; Amgalan et al., 2016; Hasenkopf et al., 2016; Gunchin et al., 2019). The main discussions were conducted on the source contributions of atmospheric particulate matter in the atmosphere based on seasonal variation and PMF (positive matrix factorization) analyses. Based on an investigation of a multiseasonal long period between 2004 and 2008 (Davy et al., 2011), the combustion sources, such as coal combustion, biomass burning, and motor vehicles, dominated the fine fraction of particulate matter in Ulaanbaatar, primarily from local emission sources, but forest fires in the north can be a significant contributor to biomass burning concentrations over time. Crustal dust sources were the primary contributors to the coarse particle fraction $\left(\mathrm{PM}_{2.5-10}\right)$. For the study period, at the site of city center (National University of Mongolia), the distributions of source contribution of the coarse particulate matter $\left(\mathrm{PM}_{2.5-10}\right)$ 
(a)

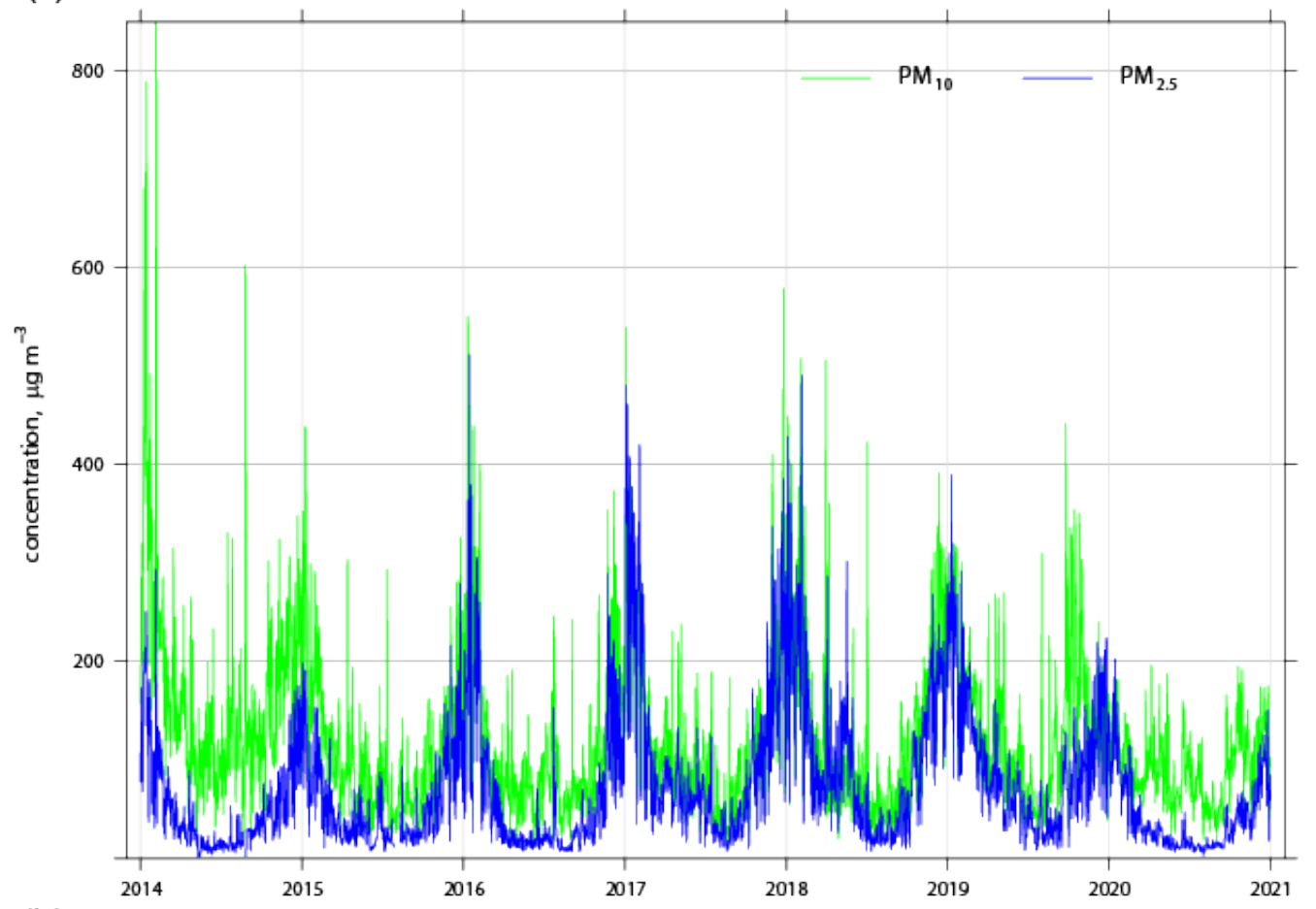

(b)

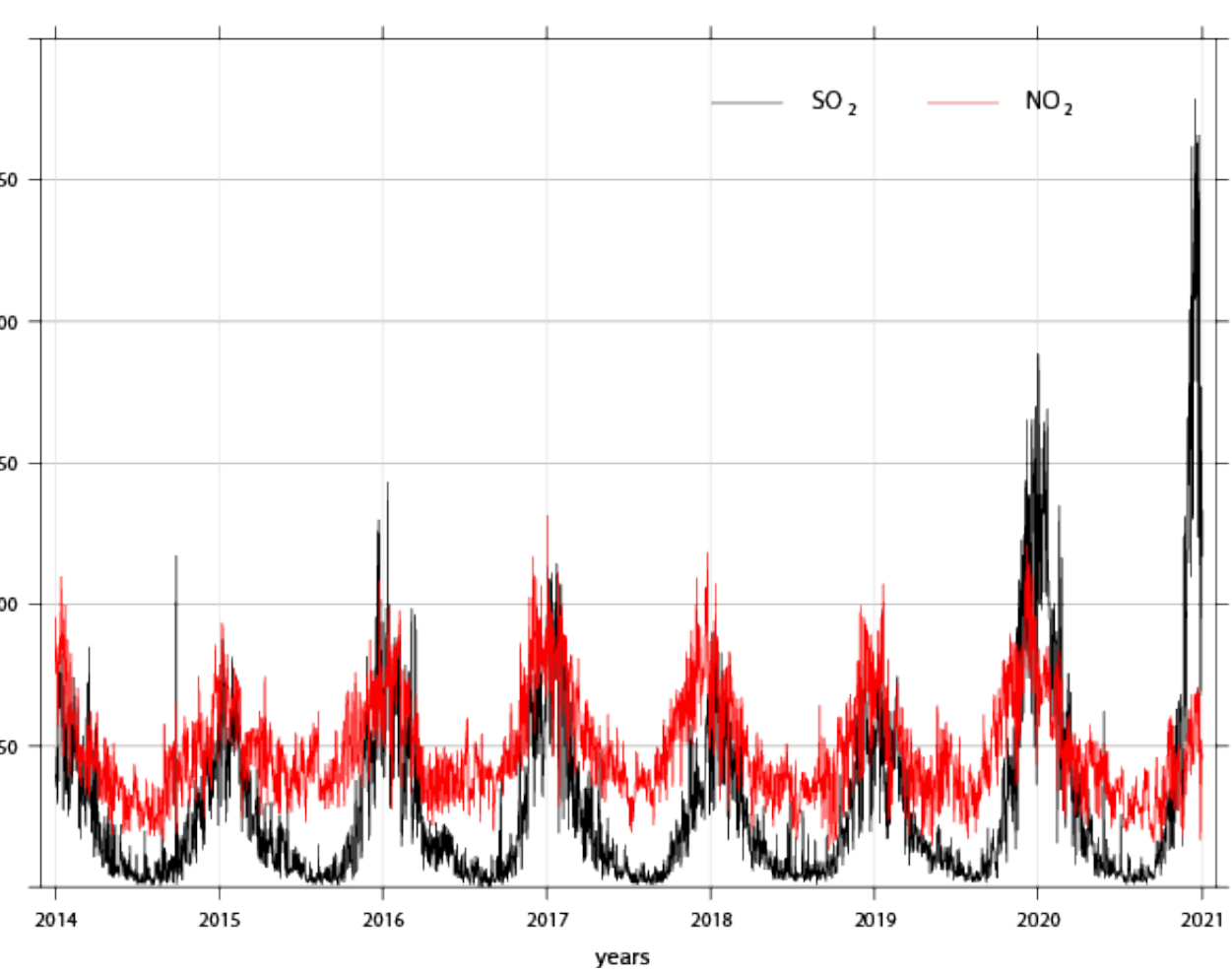

Fig. 3. Daily mean concentrations of (a) $\mathrm{PM}_{10}, \mathrm{PM}_{2.5}$ and (b) $\mathrm{SO}_{2}, \mathrm{NO}_{2}$ for 2014-2021 averaged over the $\mathrm{AQ}$ monitoring sites in Ulaanbaatar.

were in the order: soil > road dust > combustion, while of the fine particulate matter $\left(\mathrm{PM}_{2.5}\right)$, more categories were separated and in the order: combustion $>$ soil $>$ road dust $>$ motor vehicles $>$ biomass burning. There was also an unknown source grouped with high $\mathrm{Zn}$ loading for fine aerosols (Davy et al., 2011). In addition, the results of different studies on source contributions for particulate matter can differ depending on time and locations of the studies. In an investigation by Amgalan et al. (2016) using the same techniques as Davy et al. (2011), source contribution of 
$\mathrm{PM}_{2.5}$ were observed at two suburban ger areas of the city over the period of Sep 2012-Aug 2013. In the ger area, the source contribution of $\mathrm{PM}_{2.5}$ aerosols were determined in the following order: combustion $>$ road dust $>$ motor vehicles $>$ soil. At another site located in the eastern part of the city, the contribution of $\mathrm{PM}_{2.5}$ changed to the following order: soil > combustion > motor vehicle $>$ road dust (Amgalan et al., 2016).

While numerous studies of approaches on elemental composition and organic compounds (described in the next section) in PM have been carried out, the only study was recently conducted on chemical speciation of zinc ( $\mathrm{Zn})$ and chromium $(\mathrm{Cr})$ in aerosols. Gunchin et al. (2021) introduced a chemical speciation analysis of two elements in fine $\left(\mathrm{PM}_{2.5}\right)$ and coarse $\left(\mathrm{PM}_{2.5-10}\right)$ particulate matters based on the results of X-Ray Absorption Near-edge Structure Spectroscopy measurements. According to the results, chromium $(\mathrm{Cr})$ was dominant in the form of tri-valent chromium sulfate $\left(\mathrm{Cr}_{2}\left(\mathrm{SO}_{4}\right)_{3}\right)$ and chromium oxide $\left(\mathrm{Cr}_{2} \mathrm{O}_{3}\right)$ for both $\mathrm{PM}_{2.5}$ and $\mathrm{PM}_{2.5-10}$ fractions. Relative abundances of those forms were varied between the samples, but no direct relation was observed with $\mathrm{Cr}$ and $\mathrm{S}$ concentrations in aerosol. Two abundant speciation of $\mathrm{Zn}$ - sulfate $\left(\mathrm{ZnSO}_{4}\right)$ and silicate $\left(\mathrm{Zn}_{2} \mathrm{SiO}_{4}\right)$ were identified for both fine and coarse PM fractions. $\mathrm{Zn}$ oxalate $\left(\mathrm{ZnC}_{2} \mathrm{O}_{4}\right)$ was determined in fine particles, while $\mathrm{Zn}$ chloride $\left(\mathrm{ZnCl}_{2}\right)$ in the coarse particles and the relative abundances of the species of $\mathrm{Cr}$ and $\mathrm{Zn}$ were also had no direct relation with the concentrations of $\mathrm{Zn}, \mathrm{S}, \mathrm{Si}$, and $\mathrm{Cl}$. The authors concluded that $\mathrm{Cr}$ and $\mathrm{Zn}$ were mainly originated from anthropogenic sources - combustion and resuspension of dust particles due to traffic (Gunchin et al., 2021).

\section{b) Combined approaches for chemical composition and sources}

The chemical compositions of atmospheric fine aerosols $\left(\mathrm{PM}_{2.5}\right)$ in Ulaanbaatar city including water-soluble organic acids (Jung et al., 2010) and ionic, elemental, and carbonaceous compounds (organic and black carbon) were investigated during winter haze events (Jung et al., 2010; Nishikawa et al., 2011; Batmunkh et al., 2013) and compared with those of the warm season (Nishikawa et al., 2011). According to these earlier studies performed decade ago, ionic, metallic, and carbonaceous compositions of particulate matter in Ulaanbaatar $\left(\mathrm{PM}_{2.5}\right.$ and $\left.\mathrm{PM}_{10}\right)$ are attributed mostly to coal combustion products in the winter (heating) period (Nishikawa et al., 2011; Batmunkh et al., 2013). Carbon components (OC and EC) are dominant in $\mathrm{PM}_{10}$ for both heating $(47 \%)$ and nonheating (33\%) seasons in Ulaanbaatar air (Nishikawa et al., 2011). Concentrations of OC (EC) were ranged between $45.4 \mu \mathrm{g} \mathrm{m}^{-3}$ and $119 \mu \mathrm{g} \mathrm{m}^{-3}\left(18.7 \mu \mathrm{g} \mathrm{m}^{-3}\right.$ and $\left.30 \mu \mathrm{g} \mathrm{m}^{-3}\right)$ in heating season and between 10.1-27.3 $\mu \mathrm{g} \mathrm{m}^{-3}$ (4.31-8.28 $\mu \mathrm{g} \mathrm{m}^{-3}$ ) in non-heating season (Nishikawa et al., 2011). During the same year in winter (2008), the organic mass carbon content in $\mathrm{PM}_{2.5}$ counted $62.7 \%$, and the content of ammonium sulfate followed, with a $12.6 \%$ contribution (Batmunkh et al., 2013). Elemental concentration and their ratios are clearly distinguished for different sampling periods due to their dominant sources, e.g., coal combustion in heating season, while soil dust resuspension in non-heating season. The research by Jung et al. (2010) firstly reported the dicarboxylic acids, ketocarboxylic acids, and $\alpha$-dicarbonyls, and as well as soluble inorganic ions of $\mathrm{PM}_{2.5}$. The most part of aerosols were composed from emissions from local sources and as well as weather/geographical condition is a key factor of occurrence of haze events. Distributions of dicarboxylic acids and related compounds were determined to have a predominance of terephthalic acid followed by oxalic, succinic, glyoxylic, and phthalic acids (Table 3), which indicated a significant contribution from the uncontrolled burning of plastic materials in home stoves for heating and waste incineration during the cold winter (Jung et al., 2010).

Recently, Nirmalkar et al. (2020) conducted research on estimation of organic carbon emissions from biomass burning in Ulaanbaatar based on organic carbon (OC) and elemental carbon (EC), anhydrosugars (levoglucosan, mannosan, and galactosan), and water-soluble ionic composition. Biomass and coal burning and followed by soil dust and secondary aerosols formation were the major sources of $\mathrm{PM}_{2.5}$. Similar to previous findings, in winter and spring, the OC was found to be a major component in $\mathrm{PM}_{2.5}$ constituting $64 \%$ and $56 \%$, respectively, and $68 \%$ and $63 \%$ of the OC were emitted from biomass burning, respectively. The indicator compounds such as levoglucosan/ mannosan and levoglucosan $/ \mathrm{K}^{+}$ratios revealed that the softwood burning aerosols in Ulaanbaatar is a major source of organic carbon in $\mathrm{PM}_{2.5}$. Multivariate correlation analysis identified that nonbiomass burning organic carbon is dominantly produced by coal burning and followed by vehicle and vegetative emissions (Nirmalkar et al., 2020). 
Table 3. Concentrations of dicarboxylic acids and related compounds in $\mathrm{PM}_{2.5}$ of Ulaanbaatar (Jung et al., 2020).

\begin{tabular}{lll}
\hline Compounds & Concentration, $\mathrm{ng} \mathrm{m}^{-3}$ & Percentage in total organic acids, \% \\
\hline Terephthalic acid & $130 \pm 51$ & 19 \\
Oxalic acid & $107 \pm 28$ & 15 \\
Succinic acid & $63 \pm 20$ & 9 \\
Glyoxylic acid & $55 \pm 18$ & 8 \\
Phthalic acid & $54 \pm 27$ & 8 \\
\hline
\end{tabular}

Soil dust contributions existed with almost the same contributions in two seasons, heating (January) and non-heating (June) (Nishikawa et al., 2011). The meteorological conditions were determined to be the most impactful factor on the particulate matter concentration level in Ulaanbaatar (Jung et al., 2010; Batmunkh et al., 2013). During high-speed windy days with low atmospheric pressure (LP), the PM concentrations were lower by a factor of two or three than those on high-pressure days with a comparably stable stagnant atmosphere (Batmunkh et al., 2013). Most of the air pollutants were directly emitted from local sources such as heat and power plants, home stoves, and automobiles during the winter season (Jung et al., 2010).

\section{c) Organic pollutants}

Since the main producer of atmospheric pollution in the city is coal combustion (Guttikunda et al., 2013; JICA, 2017), trace amounts of organic toxic compounds that are emitted by incomplete combustion (i.e., various types of PAHs) (Bari et al., 2010; Sarigiannis et al., 2015) are expected to be present at high concentrations in the air of Ulaanbaatar. However, very few research studies have been performed and published internationally on this topic. Total suspended particles (TSPs) collected from five different locations of the city for the heating and non-heating period of 2017 were investigated by Byambaa et al. (2019). The total PAH concentrations (15 priority PAHs) ranged between 131 and $773 \mathrm{ng} \mathrm{m}^{-3}$ in winter, 22.2 and $530.6 \mathrm{ng} \mathrm{m}^{-3}$ in spring, and 1.4 and $54.6 \mathrm{ng} \mathrm{m}^{-3}$ in autumn and showed a high risk for inhabitants, with the PAH levels exceeding the World Health Organization guidelines in winter (Byambaa et al., 2019). In addition, a significantly higher concentration of 16 priority PAHs in inhalable particulate matter $\left(\mathrm{PM}_{2.5}\right)$ in the ambient air of the ger area in Ulaanbaatar was observed during the transition period between the heating and non-heating periods (Feb-Apr 2019) (Lorentz et al., 2019). The risk level of PAHs bound to $\mathrm{PM}_{10}$ was calculated to be extremely high (with a benzo[a]pyrene equivalent factor of $32 \pm 17$ ) and similar to that in the most polluted industrial city, Tianjin in China ( $29.7 \pm 15.1$ recalculated) (Jin et al., 2018). Further detailed investigations on PAHs for fine atmospheric PM including size and molecular distributions as well as different source contributions and impacting parameters are urgently needed in Ulaanbaatar city to provide guidance to people to avoid exposure to such highly toxic carcinogenic compounds. It can also be noted that in addition to evaluation of the pollution level in ambient air, atmospheric transfer mechanisms, which depend on the climatic factors in the city air, as well as environmental fate and transfer through the geochemical cycle in certain conditions of the country can be important research topics.

\section{d) Dust deposition}

Lee et al. (2018) investigated size and chemical composition of a fine fraction $(<2.5 \mu \mathrm{m})$ of road dust collected from two locations in Ulaanbaatar and compared with those in Gwangju, South Korea. The authors found greater fractions of ultrafine fine $(\sim 30 \mathrm{~nm})$ particles in UB road dust with comparably higher concentrations of $\mathrm{As}_{1} \mathrm{SO}_{4}{ }^{2-}$, and $\mathrm{Cl}^{-}$and is indicated significant impact of residential coal/biomass burning. In a recent study, application of chemical methods of atmospheric dry deposited dust is used to determine the sources for the seven potentially toxic metals ( $\mathrm{As}, \mathrm{Co}, \mathrm{Cr}, \mathrm{Cu}, \mathrm{Ni}, \mathrm{Pb}$, and $\mathrm{Zn}$ ) in heating season based on settled dust analyses sampled at 57 sites in Ulaanbaatar (Batbold et al., 2021). The results showed that the metals composition in settled dust are attributed to coal combustion, vehicle exhaust emission, and soil particles. Southern part of the city is enriched with comparably high concentrations of $\mathrm{As}, \mathrm{Zn}, \mathrm{Cu}$, and $\mathrm{Cr}$ when compared to other parts of the city and are mainly attributed to coal combustion sources. 


\subsubsection{Physical properties}

The size distribution of the nanosized fraction of ambient air particulate matter along the roadside was investigated by Oyungerel et al. (2012). Snow samples collected from twelve locations of the city were used for particle size and size distribution analysis by photon cross-correlation spectroscopy. The particle mean diameters were found to be from 1.1 to $2.5 \mu \mathrm{m}$, ranging between $74 \mathrm{~nm}$ and $4.0 \mu \mathrm{m}$. Ultrafine particles or nanoparticles $(0.02 \%$ volume percent) were found in the range of $74-100 \mathrm{~nm}$, while $83.73 \%$ fine particles $\left(\mathrm{PM}_{2.5}\right)$ were found in the range of $100 \mathrm{~nm}-2.4 \mu \mathrm{m}$, and $16.25 \%$ coarse particles $\left(\mathrm{PM}_{10}\right)$ were found in the range of $2.4-4.0 \mu \mathrm{m}$. Aerosols along the road had a high content of $\mathrm{PM}_{2.5}$ particles (Oyungerel et al., 2012). Hasenkopf et al. (2016) studied the particle sizes, shapes, and ice-nucleating properties of particulate matter collected during different seasons. As a result, all particles are in the inhalable range, with almost all particles smaller than $2.5 \mathrm{~mm}$, composed of minerals, soot, and sulfate-organic compounds. The particle concentration and sulfur content of particles increase in winter with lower ice nucleation activity (Hasenkopf et al., 2016). Moreover, the hygroscopic property of water-soluble organic-enriched aerosols in Ulaanbaatar during the winter of 2007 was investigated by Jung et al. (2011). The authors found that hygroscopic growth of water-soluble organic matter (WSOM) in at RH $85 \%$ $(\mathrm{g}(85 \%))$ is ranged between 1.11 and 1.35 (avg. $1.23 \pm 0.10)$, which are comparable to those of the biomass burning aerosols (Jung et al., 2011).

\subsubsection{Other pollutants}

a) Sulfur dioxide $\left(\mathrm{SO}_{2}\right)$

As expected, in Mongolia, $\mathrm{SO}_{2}$ pollution in winter is more serious than that in the other three seasons. According to the observational data from 1996-2009 at the AQ monitoring sites in Ulaanbaatar (UB1, UB2, UB3, and UB4, see Table 1), the daily mean concentrations of $\mathrm{SO}_{2}$ were $27.3 \pm 24.7 \mu \mathrm{g} \mathrm{m}^{-3}$ and increased dramatically during the study period (Luvsan et al., 2012). The observed results are attributed to the use of raw coal in ger area for heat production over the years, where this coal without a washing pretreatment contains a significant amount of sulfur (Prikaz et al., 2018). The main $\mathrm{SO}_{2}$ emitters in Ulaanbaatar are combustion sources such as ger stoves, traffic and power plants. All seasonal fluctuations in $\mathrm{SO}_{2}$ emissions are shown to be due to the increase in fuel consumption requirements in cold weather conditions (Luvsan et al., 2012). Prikaz et al. (2018) investigated source areas of $\mathrm{SO}_{2}$ in Ulaanbaatar based on whole-year data of air pollutants $\left(\mathrm{NO}_{\mathrm{x}}, \mathrm{NO}, \mathrm{NO}_{2}, \mathrm{O}_{3}, \mathrm{CO}, \mathrm{PM}_{10}, \mathrm{PM}_{2.5}\right.$, and $\left.\mathrm{PM}_{1}\right)$ measured at the APRD3 site (Fig. 1) and using HYSPLIT backward trajectory analyses (Prikaz et al., 2018). According to the results, in 2017, the annual average concentration of $\mathrm{SO}_{2}$ at the site was $32.43 \mu \mathrm{g} \mathrm{m}^{-3}$ and the hourly maximum concentration reached $233.2 \mu \mathrm{g} \mathrm{m}^{-3}$ in January. Back trajectory analyses showed that $78.8 \%$ of the total trajectories in Ulaanbaatar came from an area inside Mongolia.

Fig. 3(b) shows a noticeable variation of $\mathrm{SO}_{2}$ with seasons and worsened $\mathrm{SO}_{2}$ pollution in recent years in Ulaanbaatar city. The seasonal variation of $\mathrm{SO}_{2}$ is similar to that of particulate matter showing a significantly higher concentration in winter than in summer. Compared with that in winters before $2018 / 2019, \mathrm{SO}_{2}$ increased by $41 \%$ in the following two winters, which has already elicited concerns. However, no study to date has yet elaborated and reported the recent increase in $\mathrm{SO}_{2}$ concentration in Ulaanbaatar. Sulfur content in briquette fuel is $\sim 0.9 \%$ (MNIA, 2019) and is not exceeding the National Standard (MNS 5679:2019, <1.0\% S), however, is approximately two times higher than that in Baganuur coal $(0.42 \%$ S) (JICA, 2013), previously used as the main fuel of residences of Ulaanbaatar's ger area before the substitution to briquette in 2019. Thus, further investigation is needed by combining of fuel's characteristics (e.g., caloric values, compositions, and ash contents), emissions to propose adequate measures to reduce $\mathrm{SO}_{2}$ pollution in Ulaanbaatar.

As shown in Table 2, the source apportionment studies for the $\mathrm{SO}_{2}$ level and sulfur compounds in the particulate matter have not been sufficiently conducted in Mongolia. Spatial distributions of $\mathrm{SO}_{2}$ and source characteristics across Ulaanbaatar were investigated by Huang et al. (2013). The authors collected multiseasonal passive samples from 38 locations in 2011-2012 and evaluated the impact of land use patterns on $\mathrm{SO}_{2}$ and $\mathrm{NO}_{2}$ distributions by multiple regression models. The $\mathrm{SO}_{2}$ concentrations were $121.9 \mu \mathrm{g} \mathrm{m}^{-3}$ in the cold season and $46.62 \mu \mathrm{g} \mathrm{m}^{-3}$ in the moderate season (units were converted from $\mathrm{ppb}$ in original). Ger area sites showed significantly 
higher $\mathrm{SO}_{2}$ concentrations than non-ger area sites $\left(60.09 \mu \mathrm{g} \mathrm{m}^{-3}\right.$ and $32.78 \mu \mathrm{g} \mathrm{m}^{-3}$, respectively). These results also supported that the main source of atmospheric $\mathrm{SO}_{2}$ in the winter season is coal combustion in ger areas (Huang et al., 2013).

On the other hand, when considering the recent increase in vehicle and fuel consumption accordingly in the city due to an increasing population and number of vehicles, a high contribution from fuel combustion to the urban atmosphere is expected. This expectation is supported by the analytical results of fuels used in Mongolia. According to the Tables 1 and 2 of Bayasgalan et al. (2018), there are extremely high concentrations of sulfur in gasoline (117-400 ppm S) and diesel (1,135-1,165 ppm S) used in Mongolia, exceeding the Euro 4 standard (50 ppm S) by 2-8 times and 22-23 times, respectively (Bayasgalan et al., 2018). So far, there have been no reported contributions of $\mathrm{SO}_{2}$ from other sources related to industrial activities within the Ulaanbaatar city. Thus, detailed studies on the source contributions of $\mathrm{SO}_{2}$ and sulfur compounds in the atmospheric particulate matter would have been one of the urgently needed research topics.

\section{b) Nitrogen dioxide $\left(\mathrm{NO}_{2}\right)$}

As described in the previous sections, in addition to coal combustion, automobile emissions play a significant role in air pollution in cities (Davy et al., 2011; Amgalan et al., 2016). For the last ten years, the number of vehicles has increased in Ulaanbaatar by a factor of 4.5 and has reached $\sim 540,000$ (Bayasgalan and Matsumoto, 2017; NSOM, 2021). Approximately $72 \%$ of all vehicles were aged more than 10 years, and most of them were second-hand (Bayasgalan and Matsumoto, 2017). In connection with automobile emissions, $\mathrm{NO}_{2}$ concentrations detected at roadside sites of NAMEM were in the range of 41-65 $\mathrm{g} \mathrm{m} \mathrm{m}^{-3}$ and exceeded national air quality guidelines for $97 \%$ of all measured days in 2014 (Bayasgalan and Matsumoto, 2017). The only study (Huang et al., 2013) reported the seasonal variation in ambient $\mathrm{NO}_{2}$ pollution, its spatial distribution, and the contributions of different sources in Ulaanbaatar. As described above, through two weeks of passive sampling at 38 locations in the warm, cold, and moderate seasons of 2011-2012, ionic analyses of the samples, and multiple regression models, ambient $\mathrm{NO}_{2}$ pollution was explained by several land-use variables. As a result, the $\mathrm{NO}_{2}$ concentrations at traffic road-side sites in the warm and moderate seasons $\left(24.16 \mu \mathrm{g} \mathrm{m}^{-3}\right.$ and $38.51 \mathrm{\mu g} \mathrm{m}^{-3}$, respectively, units were converted from $\mathrm{ppb}$ in original) were significantly higher than those at urban sites $\left(14.3 \mu \mathrm{g} \mathrm{m}^{-3}\right.$ and $\left.27.06 \mu \mathrm{g} \mathrm{m}^{-3}\right)$. Otherwise, during the cold season, significantly higher concentrations of $\mathrm{NO}_{2}$ were observed, with an average of $66.9 \pm 19.9 \mu \mathrm{g} \mathrm{m}^{-3}$ for all sites without a clear distinction between land use types (Huang et al., 2013). Primarily, NO released into the air from the automobiles, and is converted to $\mathrm{NO}_{2}$ in the atmosphere with the presence of oxidants (e.g., ozone). The conversion rate is increased in warm and moderate season when level of ozone concentration is higher. Thus, further evaluation for the variations of $\mathrm{NO}, \mathrm{NO}_{2}$ and ozone is needed to distinguish sources contributions for $\mathrm{NO}_{x}\left(\mathrm{NO}\right.$ and $\mathrm{NO}_{2}$ ) over the year.

\section{c) Volatile organic compounds}

Volatile organic compounds (VOCs) are one group of components of air pollution comprising a complex mix of hundreds of carbon-containing gases. If VOCs occur in high concentrations in ambient air, exceeding permissible levels, then exposure can cause health risks (Han et al., 2017; Barabad et al., 2018; Kumar et al., 2018). On the other hand, VOCs are the main precursors that form secondary air pollutants such as ozone through photochemical reactions in the atmosphere especially on hot and sunny days (Han et al., 2017; Kumar et al., 2018). The assessment of VOCs is not included in air quality network monitoring in Mongolia. Regarding the lack of analytical capacity, there have been almost no attempts made to identify, quantify, and characterize VOCs in urban or rural areas in Mongolia. Much earlier, Morimo et al. (2008) detected several VOCs in urban air and reported the results in conference proceedings, but no information about sampling sites or the duration of the study was provided. Significantly elevated concentrations of VOCs were detected in Ulaanbaatar air. The concentrations of 1,3-butadiene, chloroform, and benzene in the ambient air of Ulaanbaatar were much higher than those in the Japan Environmental Standards (Morimo et al., 2008). More recently, the spatial distribution of VOCs at six sampling sites was determined within the framework of a collaborative project between German and Mongolia (Lorentz et al., 2019). Three main VOCs, BTX (benzene, toluene, xylene), were detected by passive sampling in four weeks. Similar to those in other Asian cities, the VOC levels measured 
in urban areas in Mongolia appear to be affected by automobile exhaust. The VOC concentrations near high traffic density were higher than those measured at other locations. Urban VOC emissions often represent a complex mix of traffic, industry, solvents, waste burning, and other sources (Barabad et al., 2018).

\section{d) Ozone $\left(\mathrm{O}_{3}\right)$}

Tropospheric ozone is a main secondary pollutant formed by photochemical reactions between oxides of nitrogen $\left(\mathrm{NO}_{x}\right)$ and volatile organic compounds (VOC). The precursors, $\mathrm{NO}_{x}$ and VOC, are primarily emitted by a various source in urban area including cars, power plants, industrial boilers, refineries, chemical plants, and other sources and chemically react in the presence of sunlight to produce ozone. Typically, ozone concentration is increased to unhealthy levels on hot sunny days in urban environments. Very scarce literature is available on ozone pollution in Ulaanbaatar. Dugerjav et al. (2013) analyzed ambient $\mathrm{O}_{3}$ concentration for four measuring sites of Ulaanbaatar and indicated that the daily averaged $\mathrm{O}_{3}$ were higher in summer season and were exceeded the national air quality permissible level (8-hour mean) at UB01 site and UB08 on some days (Dugerjav et al., 2013). Dorligjav et al. (2014) studied temporal variation of ground level ozone over Ulaanbaatar by using surface observation, radiosonde, and air mass back trajectory analyses during 2014. The authors noted that there is a linear relationship between the ozone and sunshine duration. The ozone concentration also showed a logarithmic relationship with water vapor and a hyperbolic relationship with $\mathrm{CO}$ and $\mathrm{NO}_{\mathrm{x}}$ (Dorligjav et al., 2014). Based on the measurements at three $\mathrm{AQ}$ monitoring sites for 2020 (Fig. 4), $\mathrm{O}_{3}$ level in Ulaanbaatar is not serious and is well below the permissible level ( $100 \mu \mathrm{g} \mathrm{m}^{-3}$, 8-hour mean) for whole year in comparison to many other cities in the world, where the $\mathrm{O}_{3}$ pollution is a serious problem. Higher level of $\mathrm{O}_{3}$ concentration is possibly related to the high traffic emission density on weekdays.

\section{FUTURE RESEARCH NEEDS}

In reviewing the current state of knowledge for urban air quality studies and overviewing the urban air quality in Mongolia, we found a growing interest in reporting fundamental studies of concentrations and physical and chemical characteristics of air pollutants in Ulaanbaatar. The
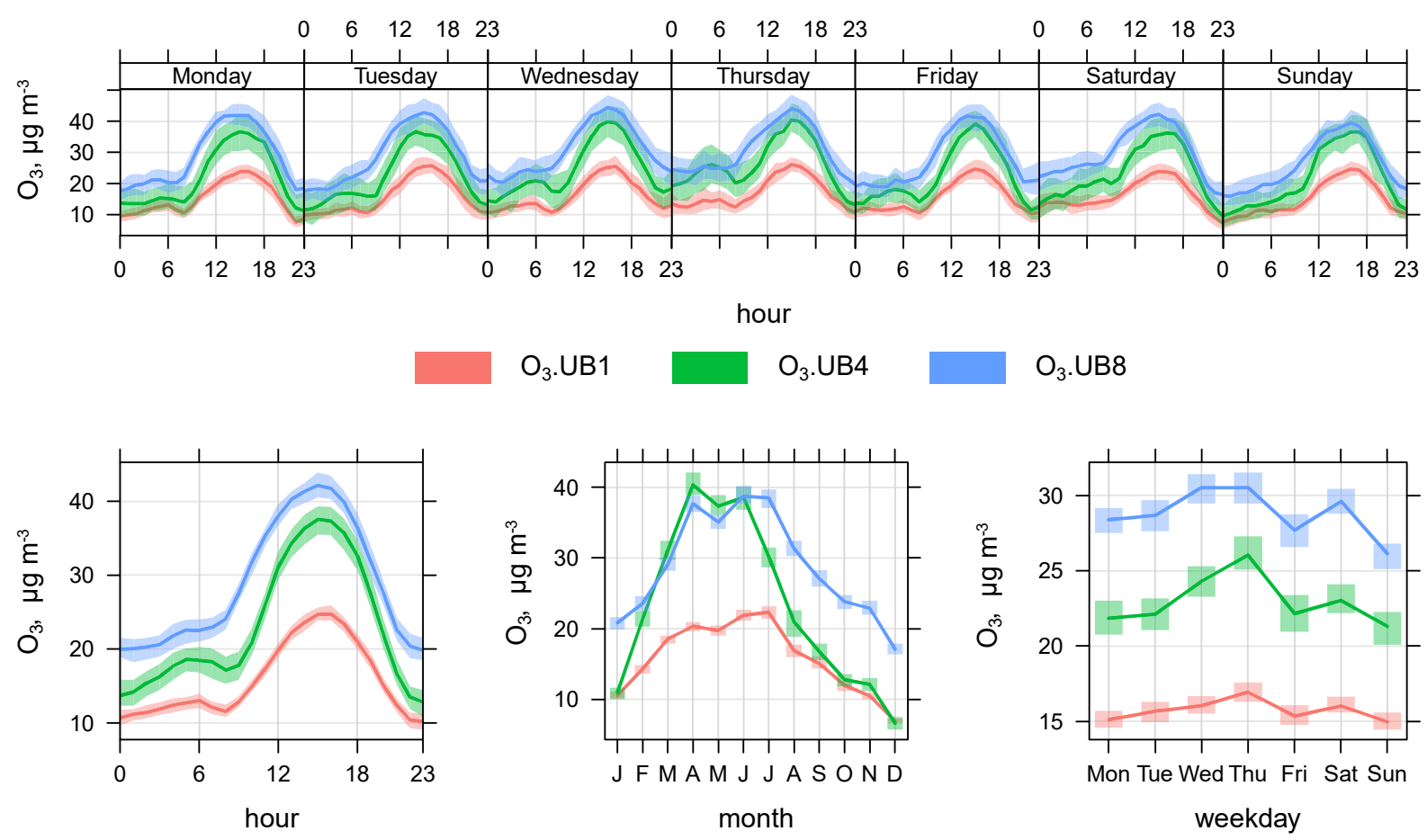

Fig. 4. Diurnal, weekly, and annual variations of ozone in Ulaanbaatar for 2020. 
frame of related scientific studies is still inadequate. Therefore, our review paper suggests several directions for future research.

To the authors' knowledge, there is no extensive scientific study reporting up-to-date emission inventory and its application in numerical modeling for scenario analysis. In addition, a better understanding of the air pollution sources and their chemical composition, stable and radiogenic isotopes and other tracer to identify source contributions and relevant studies coupled with modeling investigations are helpful for decision-makers to address the scope for policy interventions and take measures on controlling the pollutant emissions. Improvement in investigations on the source contributions of $\mathrm{SO}_{2}$ and sulfur compounds in the atmospheric particulate matter should be feasible.

Further studies on air quality issues in other industrial cities/provinces such as Darkhan and Erdenet are recommended to systematically extend the current knowledge. The establishment of air quality monitoring sites and improvement in air quality investigations need continued emphasis to provide guidance in optimizing control measures.

Studies on size distribution using cascade impactors have not been reported, and size distribution in real-time size and composition distribution measurements are also not conducted up to date. Measurements and studies on VOC and organic trace gases are still limited in Mongolia. Further improvement on the investigation of the emission and formation of organic compounds are needed. Since there is a lack of control and management system on the usage and emission of hazardous volatile compounds in Mongolia (Barabad et al., 2018; Bayasgalan et al., 2018), further investigations through long-term and multiple-point observations are strongly needed to evaluate major sources, risks to inhabitants, and possible contributions to the regional atmosphere. Future research should aim to investigate the PAHs for fine atmospheric PM in details to provide a guidance to people to avoid exposure to toxic carcinogenic compounds.

Since the introduction of briquette fuel in Ulaanbaatar, current scientific knowledge on emission inventory and source apportionment is still limited; thus, further studies should address these uncertainties. Beyond knowledge in sources, a better understanding of the vertical structure of air pollution and the relationship with weather condition in Ulaanbaatar is important to explain air pollution more in-depth. In line with the necessity of society to prevent air pollution, further research area should be expanded into the comprehensive numerical modeling and dynamical forecast of air quality in cities of Mongolia. The efforts on air quality modeling techniques of computational fluid dynamics, urban air pollution and climate integrated modeling will greatly improve understanding of air pollution behavior and its environmental impacts and enable to run future scenarios. Apart from modeling activities, measurements of different parameters in different areas, especially in obviously high polluted areas, should be extended and intensified.

Study on contributions of human activities on pollutant characteristics and behavior, such as traffic related air pollution, is suggested to be conducted. Furthermore, since the surrounding environment of the monitoring sites affect the measurement, further identification of the influencing factors on measurement sites is necessary. Since the dust storm event, the biggest source of coarse particles in non-heating season, is frequent in Mongolia, the detailed investigations to differentiate the natural and anthropogenic sources of particulate matter should be conducted.

Finally, little is known regarding the impacts of air pollution on ecosystem and urban greening. A worthwhile future endeavor would include environmental impacts of air pollution and a next step is to identify environmental risks associated with long-term air pollution in Ulaanbaatar and other urban areas in Mongolia.

\section{CONCLUSIONS}

In this paper, we present a systematic review of the studies that have investigated air pollution in Mongolia, mainly focusing on air pollution studies in Ulaanbaatar since there is a lack of comprehensive studies on air pollution in other cities. As extremely high pollution appears and becomes a major concern in Mongolia, a significant body of research has addressed the problem.

Based on this systematic review of existing research works, particulate pollution is the most severe, and it is a primary pollutant in cities of Mongolia. Studies have been adequately reported the sources and composition of particulate matter in Ulaanbaatar. Most studies focused on mass 
concentration and the chemistry (ions, metals, EC/OC) of the TSP, $\mathrm{PM}_{10}$ and $\mathrm{PM}_{2.5}$ components, however, frequent updates are essential. It is already known that an increase in $\mathrm{NO}_{2}$ is closely associated with an increase in the number of vehicles. Sulfur dioxide $\left(\mathrm{SO}_{2}\right)$ emission is mainly associated with coal combustion and partly with transport activities. Compared to a growing number of air quality studies in Ulaanbaatar, the air quality studies in other provinces are still limited. The findings on the urban air quality studies in Mongolia informs several directions for future research.

\section{ACKNOWLEDGMENTS}

The authors appreciate two anonymous reviewers for their detailed and helpful comments on the manuscript. Financial support for this work was provided by the Asia-Pacific Network for Global Change Research (CRECS2020-01) and Science and Technology Foundation of Mongolia (RUS/2019/14).

\section{REFERENCES}

Allen, R.W., Gombojav, E., Barkhasragchaa, B., Byambaa, T., Lkhasuren, O., Amram, O., Takaro, T.K., Janes, C.R. (2013). An assessment of air pollution and its attributable mortality in Ulaanbaatar, Mongolia. Air Qual. Atmos. Health 6, 137-150. https://doi.org/10.1007/s11869011-0154-3

Amarsaikhan, D., Battsengel, V., Nergui, B., Ganzorig, M., Bolor, G. (2014). A study on air pollution in Ulaanbaatar city, Mongolia. J. Geosci. Environ. Prot. 2, 123-128. https://doi.org/10.4236/g ep.2014.22017

Amgalan, N., Narantsetseg, T., Shagjjamva, D. (2016). Valuations of elemental concentrations of particle matter in Ulaanbaatar, Mongolia. Open J. Air Pollut. 5, 160-169. https://doi.org/10.42 36/ojap.2016.54012

Barabad, M.L.M., Jung, W., Versoza, M.E., Kim, M., Ko, S., Park, D., Lee, K. (2018). Emission characteristics of particulate matter, volatile organic compounds, and trace elements from the combustion of coals in Mongolia. Int. J. Environ. Res. Public Health 15, 1706. https://doi.org/10. 3390/ijerph15081706

Bari, M.A., Baumbach, G., Kuch, B., Scheffknecht, G. (2010). Particle-phase concentrations of polycyclic aromatic hydrocarbons in ambient air of rural residential areas in southern Germany. Air Qual. Atmos. Health 3, 103-116. https://doi.org/10.1007/s11869-009-0057-8

Batbold, C., Chonokhuu, S., Buuveijargal, K., Gankhuyag, K. (2021). Source apportionment and spatial distribution of heavy metals in atmospheric settled dust of Ulaanbaatar, Mongolia. Environ. Sci. Pollut. Res. 28, 45474-45485. https://doi.org/10.1007/s11356-021-13861-2

Batmunkh, T., Kim, Y.J., Jung, J.S., Park, K., Tumendemberel, B. (2013). Chemical characteristics of fine particulate matters measured during severe winter haze events in Ulaanbaatar, Mongolia. J. Air Waste Manage. Assoc. 63, 659-670. https://doi.org/10.1080/10962247.2013.776997

Batsaikhan, N., Lee, J., Nemer, B., Woo, N. (2018). Water resources sustainability of Ulaanbaatar City, Mongolia. Water 10, 750. https://doi.org/10.3390/w10060750

Baumbach, G., Vogt, U. (2003). Influence of inversion layers on the distribution of air pollutants in urban areas. Water Air Soil Pollut. 3, 65-76. https://doi.org/10.1023/A:1026098305581

Bayasgalan, B., Matsumoto, T. (2017). Estimation and prediction of road traffic emissions in Ulaanbaatar. J. JSCE 73, I_183-I_190. https://doi.org/10.2208/jscejer.73.I_183

Bayasgalan, B., Matsumoto, T., Altangerel, O. (2018). On-board measurement and emission prediction from vehicle engines using ordinary fuel and fuel additives in Mongolia. J. JSCE 6, 118-126. https://doi.org/10.2208/journalofjsce.6.1_118

Bilgili, F., Koçak, E., Bulut, Ü., Kuloğlu, A. (2017). The impact of urbanization on energy intensity: Panel data evidence considering cross-sectional dependence and heterogeneity. Energy 133, 242-256. https://doi.org/10.1016/j.energy.2017.05.121

Bolor-Erdene, D., Ganbaatar, D., Shagjjamba, D., Tugjsuren, N. (2011). The study on Ambient Air Quality in the some cities of Mongolia, Proceedings of $20116^{\text {th }}$ International Forum on Strategic Technology. IEEE, pp. 495-498. 
Byambaa, B., Yang, L., Matsuki, A., Nagato, E.G., Gankhuyag, K., Chuluunpurev, B., Banzragch, L., Chonokhuu, S., Tang, N., Hayakawa, K. (2019). Sources and characteristics of polycyclic aromatic hydrocarbons in ambient total suspended particles in Ulaanbaatar City, Mongolia. Int. J. Environ. Res. Public Health 16, 442. https://doi.org/10.3390/ijerph16030442

Cousins, S. (2019). Air pollution in Mongolia. World Health Organization. Bull. World Health Organ. 97, 79-80. https://doi.org/10.2471/BLT.19.020219

Davy, P.K., Gunchin, G., Markwitz, A., Trompetter, W.J., Barry, B.J., Shagjjamba, D., Lodoysamba, S. (2011). Air particulate matter pollution in Ulaanbaatar, Mongolia: Determination of composition, source contributions and source locations. Atmos. Pollut. Res. 2, 126-137. https://doi.org/10.5094/APR.2011.017

Dorligjav, S., Sumiya, E., Purevjav, G. (2014). Influence of photochemistry and meteorology on seasonal variation of surface ozone. National Agency for the Meteorology and Environmental Monitoring, Mongolia.

Dugerjav, O., Sato, K., Ohizumi, T. (2013). Long range transport of air pollutants (trace gases) related with meteorological process in Asia (subregion). EANET Research Fellowship Program 2013.

Fan, P., Chen, J., John, R. (2016). Urbanization and environmental change during the economic transition on the Mongolian Plateau: Hohhot and Ulaanbaatar. Environ. Res. 144, 96-112. https://doi.org/10.1016/j.envres.2015.09.020

Ganbat, G., Han, J.Y., Ryu, Y.H., Baik, J.J. (2013). Characteristics of the urban heat island in a highaltitude metropolitan city, Ulaanbaatar, Mongolia. Asia Pac. J. Atmos. Sci. 49, 535-541. https://doi.org/10.1007/s13143-013-0047-5

Ganbat, G., Baik, J.J. (2015). Local circulations in and around the Ulaanbaatar, Mongolia, metropolitan area. Meteorol. Atmos. Phys. 127, 393-406. https://doi.org/10.1007/s00703015-0374-4

Ganbat, G., Baik, J.J. (2016). Wintertime winds in and around the Ulaanbaatar metropolitan area in the presence of a temperature inversion. Asia Pac. J. Atmos. Sci. 52, 309-325. https://doi.org/10.1007/s13143-016-0007-y

Ganbat, G., Soyol-Erdene, T.O., Jadamba, B. (2020). Recent improvement in particulate matter (PM) pollution in Ulaanbaatar, Mongolia. Aerosol Air Qual. Res. 20, 2280-2288. https://doi.org/10.4209/aaqr.2020.04.0170

Gunchin, G., Manousakas, M., Osan, J., Karydas, A.G., Eleftheriadis, K., Lodoysamba, S., Shagjjamba, D., Migliori, A., Padilla-Alvarez, R., Streli, C. (2019). Three-year long source apportionment study of airborne particles in Ulaanbaatar using X-ray fluorescence and positive matrix factorization. Aerosol Air Qual. Res. 19, 1056-1067. https://doi.org/10.4209/aaqr.2018. 09.0351

Gunchin, G., Osan, J., Migliori, A., Shagjjamba, D., Streli, C. (2021). Chromium and zinc speciation in airborne particulate matter collected in Ulaanbaatar, Mongolia, by X-ray absorption nearedge structure spectroscopy. Aerosol Air Qual. Res. 21, 210018. https://doi.org/10.4209/aaqr. 210018

Guttikunda, S.K. (2008). Urban air pollution analysis for Ulaanbaatar, Mongolia. TheWorld Bank, Washington, DC.

Guttikunda, S.K., Lodoysamba, S., Bulgansaikhan, B., Dashdondog, B. (2013). Particulate pollution in Ulaanbaatar, Mongolia. Air Qual. Atmos. Health 6, 589-601. https://doi.org/10.1007/s11869013-0198-7

Han, D., Wang, Z., Cheng, J., Wang, Q., Chen, X., Wang, H. (2017). Volatile organic compounds (VOCs) during non-haze and haze days in Shanghai: Characterization and secondary organic aerosol (SOA) formation. Environ. Sci. Pollut. Res. 24, 18619-18629. https://doi.org/10.1007/s 11356-017-9433-3

Hasenkopf, C.A., Veghte, D.P., Schill, G.P., Lodoysamba, S., Freedman, M.A., Tolbert, M.A. (2016). Ice nucleation, shape, and composition of aerosol particles in one of the most polluted cities in the world: Ulaanbaatar, Mongolia. Atmos. Environ. 139, 222-229. https://doi.org/10.1016/j. atmosenv.2016.05.037

Huang, Y.K., Luvsan, M.E., Gombojav, E., Ochir, C., Bulgan, J., Chan, C.C. (2013). Land use patterns and $\mathrm{SO}_{2}$ and $\mathrm{NO}_{2}$ pollution in Ulaanbaatar, Mongolia. Environ. Res. 124, 1-6. https://doi.org/1 0.1016/j.envres.2013.02.006 
JICA (2013). Capacity Development Project for Air Pollution Control in Ulaanbaatar City Phase 3 in Mongolia. Japan International Cooperation Agency (JICA), Ulaanbaatar, Mongolia.

JICA (2017). Capacity Development Project for Air Pollution Control in Ulaanbaatar City Phase 2 in Mongolia. Japan International Cooperation Agency (JICA), Ulaanbaatar, Mongolia.

Jin, T., Han, M., Han, K., Fu, X., Xu, L., Xu, X. (2018). Health risk of ambient PM 10 -bound PAHs at bus stops in spring and autumn in Tianjin, China. Aerosol Air Qual. Res 18, 1828-1838. https://doi.org/10.4209/aaqr.2017.11.0461

Jung, J., Tsatsral, B., Kim, Y.J., Kawamura, K. (2010). Organic and inorganic aerosol compositions in Ulaanbaatar, Mongolia, during the cold winter of 2007 to 2008: Dicarboxylic acids, ketocarboxylic acids, and $\alpha$-dicarbonyls. J. Geophys. Res. 115, D22203. https://doi.org/10.102 9/2010JD014339

Jung, J., Kim, Y.J., Aggarwal, S.G., Kawamura, K. (2011). Hygroscopic property of water-soluble organic-enriched aerosols in Ulaanbaatar, Mongolia during the cold winter of 2007. Atmos. Environ. 45, 2722-2729. https://doi.org/10.1016/j.atmosenv.2011.02.055

Kumar, A., Singh, D., Kumar, K., Singh, B.B., Jain, V.K. (2018). Distribution of VOCs in urban and rural atmospheres of subtropical India: Temporal variation, source attribution, ratios, OFP and risk assessment. Sci. Total Environ. 613, 492-501. https://doi.org/10.1016/j.scitotenv.2017.09.096

Lee, K.Y., Batmunkh, T., Joo, H.S., Park, K. (2018). Comparison of the physical and chemical characteristics of fine road dust at different urban sites. J. Air Waste Manage. Assoc. 68, 812823. https://doi.org/10.1080/10962247.2018.1443855

Li, M., Zhang, Q., Kurokawa, J.-i., Woo, J.H., He, K., Lu, Z., Ohara, T., Song, Y., Streets, D.G., Carmichael, G.R. (2017). MIX: A mosaic Asian anthropogenic emission inventory under the international collaboration framework of the MICS-Asia and HTAP. Atmos. Chem. Phys. 17, 935-963. https://doi.org/10.5194/acp-17-935-2017

Liu, J., Mauzerall, D.L., Chen, Q., Zhang, Q., Song, Y., Peng, W., Klimont, Z., Qiu, X., Zhang, S., Hu, M. (2016). Air pollutant emissions from Chinese households: A major and underappreciated ambient pollution source. PNAS 113, 7756-7761. https://doi.org/10.1073/pnas.1604537113

Lodoysamba, S., Pemberton-Pigott, C. (2011). Mitigation of Ulaanbaatar city's air pollution-from source aportionment to ultra-low emission lignite burning stoves. Proceedings of International conference Towards Sustainable Energy, Solutions for the Developing World, Domestic Use of Energy, 2011.

Lorentz, H., Müller, W.J., Baumbach, G., Vogt, U., Eisold, A. (2019). Further development of air quality control planning and air quality monitoring in Ulaanbaatar (Mongolia). German Environmental Agency.

Luvsan, M.E., Shie, R.H., Purevdorj, T., Badarch, L., Baldorj, B., Chan, C.C. (2012). The influence of emission sources and meteorological conditions on $\mathrm{SO}_{2}$ pollution in Mongolia. Atmos. Environ. 61, 542-549. https://doi.org/10.1016/j.atmosenv.2012.07.044

MET (2018). Pocedure of announce Air Quality Index (AQI). http://agaar.mn/article-view/692

MET (2019). Yearly report of environmental situation of Mongolia-2017-2018 (in Mongolian). Ministry of Environment and Tourism of Mongolia.

MET (2020). Webpage of air quality announcement (agaar.mn). agaar.mn (accessed February 2020).

MNIA (2019). Web page of National Inspection Agency of Mongolia. http://home.inspection.gov. $\mathrm{mn} /$ news/295/single/1975 (accessed September 2021).

Moran, D., Kanemoto, K. (2016). Tracing global supply chains to air pollution hotspots. Environ. Res. Lett. 11, 094017. https://doi.org/10.1088/1748-9326/11/9/094017

Morimo, R., Hamada, E., Munkhbaatar, P., Dash, I., Shimotsu, Y., Iwakiri, Y., Kawasoe, M. (2008). Measurement of air quality of Ulaanbaatar City, Mongolia, 2008 Third International Forum on Strategic Technologies, pp. 656-657.

Nirmalkar, J., Batmunkh, T., Jung, J. (2020). An optimized tracer-based approach for estimating organic carbon emissions from biomass burning in Ulaanbaatar, Mongolia. Atmos. Chem. Phys. 20, 3231-3247. https://doi.org/10.5194/acp-20-3231-2020

Nishikawa, M., Matsui, I., Batdorj, D., Jugder, D., Mori, I., Shimizu, A., Sugimoto, N., Takahashi, K. (2011). Chemical composition of urban airborne particulate matter in Ulaanbaatar. Atmos. Environ. 45, 5710-5715. https://doi.org/10.1016/j.atmosenv.2011.07.029

NSOM (2021). Web page of National Statistical Office of Mongolia. (accessed June 2021). 
Oyungerel, G., Batdemberel, G., Chadraabal, S., Munkhbaatar, P., Altantsog, P. (2012). A study of nanoparticle sizes and their distributions aerosols along the road in Ulaanbaatar city, $20127^{\text {th }}$ International Forum on Strategic Technology (IFOST), pp. 1-3.

Pfeiffer, M., Batbayar, G., Hofmann, J., Siegfried, K., Karthe, D., Hahn-Tomer, S. (2015). Investigating arsenic (As) occurrence and sources in ground, surface, waste and drinking water in northern Mongolia. Environ. Earth Sci. 73, 649-662. https://doi.org/10.1007/s12665-0133029-0

Pillarisetti, A., Ma, R., Buyan, M., Nanzad, B., Argo, Y., Yang, X., Smith, K.R. (2019). Advanced household heat pumps for air pollution control: A pilot field study in Ulaanbaatar, the coldest capital city in the world. Environ. Res. 176, 108381. https://doi.org/10.1016/j.envres.2019.03. 019

Prikaz, M., Fang, C., Dash, S., Wang, J. (2018). Origin and background estimation of sulfur dioxide in Ulaanbaatar, 2017. Environments 5, 136. https://doi.org/10.3390/environments5120136

Sarigiannis, D.A., Karakitsios, S.P., Zikopoulos, D., Nikolaki, S., Kermenidou, M. (2015). Lung cancer risk from PAHs emitted from biomass combustion. Environ. Res. 137, 147-156. https://doi.org/10.1016/j.envres.2014.12.009

UNDP (2019). Air pollution in Mongolia: Opportunities for further actions. United Nations Development Program.

Wang, M., Kai, K., Jin, Y., Sugimoto, N., Dashdondog, B. (2017). Air particulate pollution in Ulaanbaatar, Mongolia: Variation in atmospheric conditions from autumn to winter. SOLA 13, 90-95. https://doi.org/10.2151/sola.2017-017

Wang, M., Kai, K., Sugimoto, N., Enkhmaa, S. (2018). Meteorological factors affecting winter particulate air pollution in Ulaanbaatar from 2008 to 2016. Asian J. Atmos. Environ. 12, 244254. https://doi.org/10.5572/ajae.2018.12.3.244

Warburton, D., Gilliland, F., Dashdendev, B. (2013). Environmental pollution in Mongolia: Effects across the lifespan. Environ. Res. 124, 65. https://doi.org/10.1016/j.envres.2013.04.002

Wesche, K., Treiber, J. (2012). Abiotic and biotic determinants of steppe productivity and performance-A view from Central Asia, Eurasian steppes. Ecological problems and livelihoods in a changing world. Springer, pp. 3-43. https://doi.org/10.1007/978-94-007-3886-7_1

Whiteman, C.D., Bian, X., Zhong, S. (1999). Wintertime evolution of the temperature inversion in the Colorado Plateau Basin. J. Appl. Meteorol. 38, 1103-1117. https://doi.org/10.1175/15200450(1999)038<1103:WEOTTI>2.0.CO;2

Yamamoto, K., Suzuki, Y., Oyunjargal, G., Fukuda, H., Oidov, M., Hasegawa, H. (2020). Inorganic and organic chemical characteristics and sources of suspended particulate matters in Ulaanbaatar, Mongolia. Geochem. J. 54, 267-276. https://doi.org/10.2343/geochemj.2.0579 